\title{
DySFUNKCJE POLSKIEGO PRAWA I KIERUNKI JEGO DOSKONALENIA NA ETAPIE PROCESU USTAWODAWCZEGO
}

Warunki proceduralne procesu ustawodawczego nigdy nie mają i nigdy nie powinny mieć charakteru skończonego, maksymalnie ukształtowanego czy też raz na zawsze zamkniętego ${ }^{1}$. Z góry założoną otwartość na korekty, zmiany, a w konsekwencji udoskonalenie procesu dochodzenia ustawy do skutku determinują, jak się zdaje, cztery zasadnicze grupy czynników, tj.: 1) epistemologiczne (związane z rozwojem stanu wiedzy oraz rozmaitych sposobów jej pozyskiwania ${ }^{2}$ ); 2) prakseologiczne (związane ze wdrażaniem coraz lepszych, z definicji bardziej racjonalnych i bardziej skutecznych narzędzi pracy); 3) jurydyczne (związane z koniecznością konkretyzacji prawnych, w tym zwłaszcza konstytucyjnych dyrektyw odnoszących się do procesu ustawodawczego, które przecież także nie są ukształtowane w sposób ostateczny o czym świadczy przykład acquis constitutionnel) i wreszcie 4) teleologiczne (które wiążą się ze zmianą celów jakie chce osiągnąć prawodawca albo przynajmniej z innym

* Prof. UW, dr hab.; Instytut Nauk Politycznych Uniwersytetu Warszawskiego; jaroslawszymanek@o2.pl.

${ }^{1}$ Stąd stosunkowo często są one przedmiotem uwag, krytyki i wniosków de lege ferenda. Por. np. A. Szmyt, Tryb stanowienia ustawy - szanse i zagrożenia, [w:] M. Granat (red.), Zagadnienia prawa parlamentarnego, Warszawa 2007, s. 107 i nast. Zob. również A. Szmyt, Węzłowe problemy procesu legsialcyjnego w Sejmie i Senacie RP, [w:] R. Arnold (red.), Festgabe zu Ehren von Andrzej Szmyt. Ausgewählte Schriften, Regensburg 2016, s. 131 i nast.

${ }^{2}$ Por. J. Wróblewski, Epistemologiczne $i$ aksjologiczne uwarunkowania tworzenia prawa, „Studia Prawno-Ekonomiczne” 1979, t. XXII, s. 7 i nast. 
ich rozkładaniem bądź akcentowaniem³ ${ }^{3}$. Pewna konieczna doza plastyczności procedur dochodzenia ustawy do skutku jest też, co jasne, konsekwencją tego, że proces ustawodawczy jest niczym innym jak tylko jedną $\mathrm{z}$ odmian procesu decyzyjnego realizowanego $\mathrm{w}$ przestrzeni publicznej ${ }^{4}$ (czyli mówiąc inaczej, procesu podejmowania decyzji politycznych ${ }^{5}$ ), a te siłą rzeczy muszą odznaczać się niezbędną elastycznościa, co oczywiście w żadnym razie nie jest równoznaczne z dowolnością czy - tym bardziej - arbitralnością kształtowania elementów proceduralnych takiego decydowania.

Dyskusję na temat ewentualnych kierunków i form doskonalenia procesu ustawodawczego, należy już na samym początku skonkretyzować i zdecydować, czy ma ona obejmować istniejące de lege lata rozwiązania konstytucyjne (które w największym stopniu kształtują model prawotwórstwa i szerzej - całego systemu prawnego, w tym systemu źródeł prawa) czy też ma być ona jednak skrępowana gorsetem obowiązujących postanowień konstytucyjnych. Uznać wypada, że formułowanie propozycji o charakterze de lega fundamentali ferenda przekracza ramy niniejszego opracowania, stąd będzie ono poruszało się w „widełkach” jakie narzuca Konstytucja Rzeczpospolitej Polskiej z dnia 2 kwietnia 1997 r. ${ }^{6}$.

Obowiązującą Konstytucję, w zakresie dotyczącym prawodawstwa, należy przy tym rozumieć dwojako. Chodzi po pierwsze o tekst obowiązującej Konstytucji RP i wyprowadzane z niego normy i zasady kształtujące proces ustawodawczy (co w skrócie można nazwać „,konstytucją tekstualną") oraz po drugie, o tzw. „konstytucję sądową”, czyli coś, co spełnia standard acquis constitutionnel, a co jest dorobkiem orzecznictwa sądów, w tym zwłaszcza Trybunału Konstytucyjnego. O tym ostatnim trzeba bezwzględnie pamiętać, gdyż z natury rzeczy ogólne, a niekiedy wręcz ogólnikowe ramy prawodawstwa wyznaczone przez Konstytucję, w bardzo wielu przypadkach sprecyzował i dookreślił Trybunał Konstytucyjny,

${ }^{3}$ A które niejednokrotnie, składając się na tzw. politykę tworzenia prawa, są czynnikiem w największym stopniu rozstrzygającym procesie prawotwórczym, jego kształcie i kierunku przebiegu. Por. Z. Ziembiński, Problemy podstawowe prawoznawstwa, Warszawa 1980, s. 374 i nast.

${ }^{4}$ Por. J Wróblewski, Teoria racjonalnego tworzenia prawa, Wrocław - Warszawa - Kraków 1985, s. 44 i nast.

${ }^{5}$ Szerzej na ten temat zob. E. Kustra, Polityczne problemy tworzenia prawa, Toruń 1994, s. 15 i nast.

${ }^{6}$ Konstytucja Rzeczpospolitej Polskiej z dnia 2 kwietnia 1997 r., Dz. U. Nr 78, poz. 483, z późn. zm., dalej jako: Konstytucja. 
czyniąc je zarazem, na równi z właściwym tekstem Konstytucji RP, kryterium oceny konstytucyjności i legalności tworzonego prawa ${ }^{7}$. Pierwszym $\mathrm{z}$ brzegu dowodem na istnienie owego acquis constitutionnel jest choćby zasada przyzwoitej (prawidłowej) legislacji, którą Trybunał wyprowadził z zasady państwa prawnego i powoli, acz bardzo konsekwentnie sformułował jako osobna, a zarazem jedną z podstawowych dyrektyw wiążących prawodawcę ${ }^{8}$, która musi być bezwzględnie spełniona pod groźbą sankcji derogacji przepisu uchybiającego tej zasadzie i warunkom na nią się składających ${ }^{9}$.

Obie konstytucje, a więc zarówno tekstualna jak i sądowa, przesądzają obecnie kilka faktów, które nawet jeśli są bądź mogą być wątpliwe, należy bezwzględnie respektować. Pierwszym z nich jest chociażby konstytucjonalizacja (wydaje się zupełnie niepotrzebna) zasady trzech czytań (art. 119 ust. 1 Konstytucji), która krępuję ustawodawcę zwykłego, ponieważ ten nie może jej w żaden sposób obejść przyjmując, np. na poziomie postanowień regulaminowych ${ }^{10}$, rozwiązania idące bądź to $\mathrm{w}$ kierunku większej bądź mniejszej liczby czytań, co w niektórych przypadkach mogłoby uprościć, a w innych wręcz przeciwnie jeszcze bardziej skomplikować i utrudnić proces ustawodawczy, choćby po to by spowolnić działania ustawodawcze i dać prawodawcy więcej namysłu do zastanowienia się i rozważenia wszytskich „za” i „przeciw” proponowanej regulacji ${ }^{11}$. Ma

7 Por. m.in.: W. Sokolewicz, Niektóre zagadnienia procedur parlamentarnych $w$ świetle orzecznictwa Trybunału Konstytucyjnego, [w:] F. Rymarz, A. Jankiewicz (red.), Trybunat Konstytucyjny. Księga XV-lecia, Warszawa 2001, s. 168 i nast.; M. Zubik, Prawo parlamentarne i postepowanie ustawodawcze w orzecznictwie Trybunatu Konstytucyjnego, [w:] F. Rymarz, A. Jankiewicz (red.), Księga XX-lecia orzecznictwa Trybunału Konstytucyjnego..., s. 693 i nast.; J. Szymanek, Sejm, Senat a Trybunał Konstytucyjny. Współzależności w kształtowaniu systemu prawnego państwa, "Przegląd Legislacyjny” 2004, nr 4, s. 35 i nast.

${ }^{8}$ Por. S. Wronkowska, Zasady przyzwoitej legislacji w orzecznictwie Trybunału Konstytucyjnego, [w:] M. Zubik (red.), Ksiega XX-lecia orzecznictwa Trybunału Konstytucyjnego, Warszawa 2006, s. 671 i nast.

${ }^{9}$ Inna sprawa, że zasada ta, jak przystało na właściwą zasadę, może być spełniona bądź niespełniona w bardzo różnym (niejednakowym) stopniu, co per se nie musi wcale oznaczać zawsze i wszędzie stwierdzenia niekonstytucyjności normy uchybiającej (w jakiś sposób) tej zasadzie, a w konsekwencji jej wyprowadzenia z systemu obowiązujących norm prawa stanowionego.

${ }_{10}$ Które w zakresie ukształtowania procedur legislacyjnych mają olbrzymie, a w praktyce najpoważniejsze znacznie. Szerzej na ten temat zob. J. Jaskiernia, Regulacja prawna procedur parlamentarnych, „Państwo i Prawo” 1994, nr 12, s. 18 i nast.

11 Por. Z. Jarosz, Postępowanie ustawodawcze w Sejmie, [w:] J. Wawrzyniak (red.), Tryb ustawodawczy a jakość prawa, Warszawa 2005, s. 85 i nast. 
to swoje ujemne skutki choćby $\mathrm{w}$ regulaminowej detalizacji postępowania w ramach tzw. trybu pilnego, który za sprawą art. 119 ust. 1 Konstytucji musi być prowadzony obowiązkowo w formule trzech czytań, co całą konstrukcję trybu pilnego lekko podważa ${ }^{12}$. Z kolei z obszaru „konstytucji sądowej" należy wskazać wypracowaną przez sam Trybunał Konstytucyjny, choć ciągle dyskusyjną, koncepcję możliwości zajęcia się tzw. „pominięciem ustawodawczym” (które Trybunał poddał swojej ocenie), zaś pozostawieniem poza jego kognicją tzw. „zaniechania ustawodawczego”. Z obszaru „konstytucji sądowej” należy jeszcze wskazać, że choć Trybunał wprost zadeklarował, iż ocena celowości i trafności rozstrzygnięć prawodawczych „wykracza poza zakres kompetencji sądownictwa konstytucyjnego"13, które spełnia co do zasady model prawodawcy negatywnego, to jednak, okazjonalnie mogą być one poddane ocenie Trybunału, szczególnie wówczas, kiedy prawodawca „przekroczy zakres swej swobody regulacyjnej"14, co z kolei przekształca sąd konstytucyjny $\mathrm{w}$ ustawodawcę po części przynajmniej pozytywnego ${ }^{15}$.

Ewentualne kierunki i formy optymalizacji procesu legislacyjnego winny zatem uwzględniać po pierwsze konstytucyjne wyznaczniki prawotwórstwa, przy czym chodzi tu zarówno o konstytucję „tekstualną", jak i „sądową"; po drugie, konstytucyjne determinanty parlamentarnego systemu rządów, z tym jednak, że wysoce zracjonalizowanego; po trzecie wreszcie, dyrektywy jakie wynikają z racjonalnego modelu tworzenia prawa, który to model choć bywa przedmiotem dyskusji, a niekiedy wręcz krytyki wciąż pozostaje obowiązującym paradygmatem prawotwórstwa ${ }^{16}$. Pamiętać też trzeba, że nie wszystkie mankamenty obecnie realizowanego

12 Tryb ten obarczony jest zresztą i innymi mankamentami. Szerzej na ten temat zob. S. Patyra, Tryb pilny w sejmowym postępowaniu ustawodawczym - reguta czy wyjatek?, [w:] W. Brzozowski, A. Krzywoń (red.), Leges ab amnibus intellegi debent. Księga XV-lecia Rządowego centrum Legislacji, Warszawa 2015, s. 340 i nast.

${ }_{13}$ Wyrok z dnia 22 czerwca 1999 r., sygn.. akt K5/99, OTK ZU 1999, nr 5, poz. 100.

${ }_{14}$ Wyrok z dnia 8 kwietnia 1998 r. sygn. akt K10/97, OTK ZU 1998, nr 3, poz. 29.

15 Szerzej na ten temat zob. R. Piotrowski, Racjonalność, rzetelność i sprawność jako przestanki oceny zgodności ustawy z konstytucja, [w:] P. Mikuli A. Kulig ,J. Karp, G. Kuca (red.), Ustroje. Tradycje i porównania. Księga jubileuszowa dedykowana prof. dr. hab. Marianowi Grzybowskiemu w siedemdziesiata rocznice urodzin, Warszawa 2015, s. 811 i nast.

${ }^{16}$ Szerzej na ten temat zob. Por. Z. Ziembiński, Problemy podstawowe..., s. 388 i nast. Szerzej na ten temat zob. H. Rot, Wartości proceduralne tworzenia prawa. Studium legislacji porównawczej, Wrocław 1992, s. 85 i nast. 
procesu ustawodawczego ${ }^{17}$ można zlikwidować czy chociażby zminimalizować $\mathrm{w}$ drodze odpowiednich nowelizacji prawa (głównie regulaminu Sejmu ${ }^{18}$ ). Bardzo wiele $\mathrm{z}$ nich wynika bowiem nie tyle $\mathrm{z}$ wadliwie czy wręcz nieracjonalnie skonstruowanych przepisów odnoszących się do procedur legislacyjnych, ile ze złej praktyki oraz, co trzeba wyraźnie podkreślić, braku właściwiej kultury tworzenia prawa ${ }^{19}$. Można tutaj jedynie tytułem przykładu ${ }^{20}$ wskazać wiele dysfunkcji polskiej legislacji, których nie sposób zmienić inaczej jak tylko poprzez zmianę pewnych nawyków oraz ukształtowanie się - co wymaga niestety dłuższej perspektywy czasowej-odpowiedniego poziomu kultury prawno-politycznej ${ }^{21}$.

Pierwszą z takich dysfunkcji jest niewątpliwie inflacja prawa. Aktów prawnych, zwłaszcza o randze ustawy, jest po prostu za dużo, a legislatorzy podnoszą do rangi normy ustawowej coraz więcej materii z rozległej sfery stosunków społeczno-gospodarczych i innych, co sprawia, że dzisiaj nie ma właściwie obszarów uwolnionych spod gorsetu regulacji ustawowej $^{22}$. Tymczasem system źródeł prawa, o czym się często zapomina, to nie tylko system hierarchicznej podległości jednej normy wobec drugiej (hierarchia w znaczeniu derogacyjnym, tj. norma wyższego rzędu uchyla normę niższego rzędu), ale to także system hierarchii (relewancji) spraw (materii), które podnosi się do rangi ustawy albo nie i uznaje, że dana sprawa nie wymaga eksponowanego aktu prawnego jakim jest ustawa, co oznacza, że można ją z powodzeniem umieścić w akcie pozostającym na niższych szczeblach prawotwórstwa, względnie pozostawić w ogóle

17 Szerzej na ten temat zob. S. Wronkowska, Proces prawodawczy dwóch dekad: sukcesy i niepowodzenia, „Ruch Prawniczy, Ekonomiczny i Socjologiczny” 2009, nr 2, s. 11 i nast.

${ }_{18}$ Por.: P. Winczorek, Opinia w sprawie postepowania legislacyjnego w przepisach regulaminu Sejmu Rzeczypospolitej Polskiej, „Przegląd Sejmowy” 2000, nr 2, s. 57 i nast.; S. Wronkowska, Opinia w sprawie postępowania legislacyjnego w przepisach regulaminu Sejmu rzeczypospolitej Polskiej, „Przegląd Sejmowy” 2000, nr 2, s. 82 i nast.

19 Przy czym zły stan tej kultury w Polsce jest, niestety, cechą właściwą dla całego regionu Europy Środkowej i Wschodniej. Szerzej na ten temat zob. T. Mijel, Europejska kultura prawna a kraje Europy Środkowej i Wschodniej, „Przegląd Legislacyjny” 2008, nr 1, s. 60 i nast.

${ }^{20}$ Dysfunkcje takie i innego rodzaju mankamenty polskiego modelu prawodawstwa, a w tym procesu ustawodawczego są od dawien dawna przedstawiane w doktrynie. Por. np.: B. Banaszak, System prawa w Polsce - stan obecny $i$ uwagi de lege ferenda fundamentali, „Przegląd Legislacyjny” 2008, nr 4, s. 56 i nast.

${ }^{21}$ Por. M. Kruk, Rozważania o ksztattowaniu się zwyczajów i obyczajów politycznych w praktyce konstytucyjnej, [w:] K. Działocha (red.), Przeobrażenia we wspótczesnym prawie konstytucyjnym, Wrocław 1995, s. 39 i nast.

${ }^{22}$ Por. M. Borucka-Arctowa, O właściwy zakres regulacji prawnej, „Państwo i Prawo” 1975, nr 2, s. 5 i nast. 
poza obszarem prawnej reglamentacji ${ }^{23}$. Drugą taką dysfunkcją jest labilność prawa. Ustawodawca zbyt często zmienia normy ustawowe, a nowelizacja stała się dzisiaj podstawową formą działania prawotwórczego ${ }^{24}$. Czasami dochodzi wręcz do kuriozalnych sytuacji, kiedy Sejm nowelizuje przepisy pozostające jeszcze w okresie vacatio legis, co poza legislacyjnym chaosem wprowadza jeszcze niepewność prawa i istotnie obniża jego prestiż. Pamiętać wszak wypada, że prawo, zwłaszcza o randze ustawy, ma być prawem szczególnego rodzaju, prawem pewnym i stabilnym, prawem, które modyfikuje się zupełnie wyjątkowo i z ważnych powodów, a nie przy każdej nadążającej się ku temu okazji ${ }^{25}$.

Inną dysfunkcja, zahaczającą już o stan patologii, jest bardzo często brak precyzyjnego wskazania celu tworzonego prawa ${ }^{26}$. Ta dysfunkcja, jak mało która pokazuje, że przepisy proceduralne nie zawsze są wystarczającą zaporą przed tworzeniem prawa w sposób niewłaściwy. Normy regulaminowe wskazują bowiem wyraźnie, że każdy inicjator projektu ustawy musi określić cel projektowanej regulacji. Tymczasem w bardzo wielu przypadkach cel albo nie jest w ogóle wskazany, ale jest wskazany w sposób wysoce abstrakcyjny (co często wyklucza możliwość jego określenia) albo jest wskazany nieprawidłowo. Nieokreślenie albo określenie z niedostateczną precyzją celu ustawy wywołuje jeszcze jeden, wysoce negatywny skutek. Jest nim (a przynajmniej może być) zaburzenie ról legislacyjnych, co dotyczy zwłaszcza Sejmu i Trybunału Konstytucyjnego. W praktyce bowiem, przy absencji celu wskazanego przez prawodawcę wysuwa się pod adresem Trybunału Konstytucyjnego oczekiwanie sformułowania celu i odpowiedzenia na pytanie „co właściwie chciał osiągnać ustawodawca”. Pytanie takie jest zaś pytaniem par excellence politycznym, gdyż wybór i hierarcha celów to nic innego jak działania polityczne, a Trybunał Konstytucyjny nie jest (nie powinien być) sądem politycznym tylko sądem nad prawem ${ }^{27}$. Jeszcze inną dysfunkcja polskiej legislacji jest

${ }^{23}$ Co oczywiście współcześnie zdarza się coraz rzadziej.

${ }^{24}$ Szerzej na ten temat zob. P.E. Zwierzykowski, Nowelizacja jako sposób zmiany prawa. Studium z teorii legislacji, Poznań 2016, s. 165 i nast.

${ }^{25}$ Szerzej na ten temat zob. P. Sobczyk, Ustawa jako akt parlamentu ustanowiony w szczególnym trybie, [w:] M. Karpiuk (red.), Akty normatywne i administracyjne, Warszawa 2009, s. 45 i nast.

${ }^{26}$ Co zawsze powinno być pierwszym zadaniem racjonalnego ustawodawcy. Por. Z. Ziembiński, Problemy podstawowe..., s. 403 i nast.

${ }^{27}$ Niezależnie od tego, ze bardzo często jest on tak postrzegany. Por. R. Albeski, Trybunat Konstytucyjny w polskich systemach politycznych, Wrocław 2010, s. 212 i nast. 
często brak wystarczającej określoności prawa. Tymczasem w demokratycznym państwie prawa, w państwie gdzie proces tworzenia prawa rządzi się zasadami przyzwoitej legislacji normy prawne muszą być określone, tzn. takie żeby ich adresaci mogli w sposób niebudzący wątpliwości zrekonstruować wzorzec nakazanego (zakazanego bądź powinnego) zachowania ${ }^{28}$. Brak dostatecznej określoności prawa narusza bowiem pewność prawa i generuje efekt jego dyskrecjonalności poprzez stwarzanie systemu zachęt do jego rożnej (dowolnej) interpretacji. Często towarzyszy temu kolejna dysfunkcja, jaką jest brak wystarczającej jasności (komunikatywności) prawa ${ }^{29}$. Prawo zaś, żeby spełniało wszystkie przypisywane mu funkcje, musi być sformułowane w sposób jasny, czytelny, zrozumiały dla odbiorcy ${ }^{30}$. Jeśli tych kryteriów prawo nie spełnia, jest po prostu złym prawem, prawem niezrozumiałym, prawem, które nie może we właściwy osób kształtować treści stosunków prawnych ${ }^{31}$. Poważną dysfunkcją legislacji jest też transgresja prawa. Składają się na nią dwa pomniejsze zjawiska, mianowicie transgresja hierarchiczna, przez którą należy rozumieć zamieszczanie $\mathrm{w}$ poszczególnych aktach prawnych norm treściowo dla nich nieadekwatnych. Przykładem, niestety dosyć częstym, może być tutaj umieszczanie $\mathrm{w}$ ustawie przepisów merytorycznie pozaustawowych, których właściwym miejscem jurydyzacji winno być rozporządzenie. Jak nietrudno zauważyć praktyka taka przyczynia się, w dalszej kolejności, do nadmiernej detalizacji ustawy, co w efekcie wywołuje inflację norm o randzie ustawy. Innym rodzajem transgresji, niestety także obserwowanym w praktyce, jest transgresja merytoryczna (ontologiczna). Należy przez nią rozumieć zamieszczenie w aktach prawa stanowionego (bez względu na ich hierarchiczną postać) norm nie prawnych, ale norm wywodzących się z innych systemów normatywnych (np. moralności, religii, etyki). W swoim rezultacie transgresja merytoryczna zaburza obraz zespołu norm, który przestaje być zespołem norm różnych gatunkowo (tj. prawnych, społecznych, religijnych, moralnych, etycznych), a staje się homogenicznym zespołem norm wyłącznie prawnych. Pamiętać zaś trzeba,

28 S. Wronkowska, Podstawowe pojęcia prawa i prawoznawstwa, Poznań 2003, s. 27.

29 Por. A. Choduń, Komunikatywność języka tekstów aktów prawnych, „Przegląd Legislacyjny" 2007, nr 2, s. 90 i nast.

${ }^{30}$ Por. A. Łopatka, Kryteria jakości prawa, [w:] A. Wasilkowski (red.), Jakość prawa, Warszawa 1996, s. 28 i nast.

${ }^{31}$ Por. M. Pruszyński, Jasność, zrozumiałość i językowa poprawność prawa jako warunek jego zgodności z Konstytucja, „Przegląd Legislacyjny” 2007, nr 1, s. 77 i nast. 
że prawidłowo skonstruowany system norm wymaga istnienia wyraźnej dystynkcji między rozmaitymi normami i systemami norami, a sytuacja pokrywania się różnych ontologicznie norm, jest zawsze wyjątkiem a nie regułą. Dysfunkcją innego rodzaju jest też, spotykana coraz częściej, aksjologiczna chwiejność bądź niejednorodność prawa, albo wręcz przeciwnie, tzn. absencja wartości, do których prawo się odwołuje (bądź powinno się odwływać). Tymczasem prawo, jako swoiste narzędzie inżynierii społecznej, winno się cechować jasnym, precyzyjnym, a przede wszystkim koherentnym system wartości, które w swoim zamierzeniu preferuje i chce realizować ${ }^{32}$. Współcześnie jednak wartości prawa schodzą wyraźnie na plan dalszy (co w skrajnych sytuacjach generuje niebezpieczny nihilizm prawa) albo są tak różne, tak eklektyczne, że w swoim całokształcie niezborne i wywołują efekt odwrotny od zamierzonego ${ }^{33}$. Często też, co również jest poważną dysfunkcją prawa, uzyskują one status nadrzędny, co z kolei oznacza, że prawo w pierwszej kolejności wyraża wartości, zaś pożądane wzorce zachowania mają znaczenie wyraźnie wtórne. Tego rodzaju sytuacje składają się na kolejną, poważną dysfunkcją legislacji, jaką jest nadmierna polityzacja prawa. Chodzi o to, że przy użyciu instrumentu prawnego (tj. normy prawnej) ustawodawca stara się rozstrzygnąć problemy, które powinny być rozstrzygane za pomocą innych narzędzi. Przez polityzację prawa należy również rozumieć sytuację zaburzenia dyskursu prawniczego ( $\mathrm{zw}$. kanału komunikacji), tj. uznania, że prymitywna zasada większości jest wystarczającym, a niekiedy wręcz jedynym kryterium podejmowania decyzji prawodawczych ${ }^{34}$. Tymczasem polityczna racja przemawiająca za uchwaleniem bądź nieuchwaleniem prawa musi, co jasne, być brana pod uwagę, ale nie może uzyskać status racji dominującej czy tym bardziej rozstrzygającej.

Wskazane wyżej dysfunkcje dowodzą najlepiej, że nie da się przy użyciu prostej zmiany przepisów, a co za tym idzie - wprowadzenia rozwiązań nawet najbardziej racjonalnych, aksjologicznie i prakseologicznie

32 Por. H. Rot, Uwarunkowania i wartości procedury prawotwórczej, [w:] K. Działocha (red.), Problemy tworzenia prawa w państwie demokratycznym, Wrocław 1993, s. 111 i nast.

${ }^{33}$ Co jest m.in. powodem krytyki demokratycznego modelu prawotwórstwa, który opiera się na inkluzji wielu podmiotów zaangażowanych $\mathrm{w}$ tworzenia prawa po to, by ostatecznie ustanowiona norma prawna mogła spełniać rozmaite oczekiwania, w tym także te odnoszące się do wartości. Por. R. Piotrowski, Spór o model tworzenia prawa, Warszawa 1988, s. 179 i nast.

${ }^{34}$ Szerzej na ten temat zob. W. Cyrul, Wpływ procesów komunikacyjnych na praktyke tworzenia i stosowania prawa, Warszawa 2012, s. 222 i nast. 
uzasadnionych, wyeliminować czy tylko zminimalizować wszystkich możliwych negatywnych zjawisk, jakie trapią proces ustawodawczy. Bardzo wiele w tym obszarze pozostaje dla ujawniającej się praktyki, zwyczajów i obyczajów, kultury prawno-politycznej i tego wszystkiego co można nazywać etyką polityka (posła) i etyką legislatora ${ }^{35}$.

Można jednak pokusić się o sformułowanie kliku uwag o charakterze de lege ferenda, które z jednej strony pokażą zasadnicze kierunki pożądanego doskonalenia procesu ustawodawczego, z drugiej zaś zasugerują niektóre przynajmniej formy tego doskonalenia. Wydaje się, że ewentualne prace zmierzające do optymalizacji modelu prawotwórstwa (szczególnie na poziomie ustawy) powinny zawierać się $\mathrm{w}$ pięciu zasadniczych hasłach, mianowicie: 1) proces ustawodawczy bardziej racjonalny; 2) proces ustawodawczy bardziej profesjonalny; 3) proces ustawodawczy bardziej uspołeczniony; 4) proces ustawodawczy bardziej kontrolowany i wreszcie, co stanowić ma puentę wszystkich zabiegów modernizacyjnych 5) proces ustawodawczy bardziej efektywny. Spełnienie poszczególnych postulatów, a przynajmniej części z nich, odpowiada generalnemu modelowi racjonalnego tworzenia prawa, który to model - co należy podkreślić - pozostaje pewnym, wyidealizowanym abstraktem ${ }^{36}$, do którego demokratyczny prawodawca działający w oparciu o reguły państwa prawa, przyzwoitej legislacji oraz sprawnego i rzetelnego działania instytucji publicznych powinien za wszelką cenę dążyćc ${ }^{37}$.

\section{Racjonalność procesu ustawodawczego}

Zacząć należy od postulatu: „proces ustawodawczy bardziej racjonalny". Przez racjonalność należy w tym przypadku rozumieć zbieg trzech zasadniczych wartości (stanów rzeczy), tj.: 1) celu jaki przyświecał ustrojodawcy (autorowi Konstytucji) wprowadzającemu konkretne rozwiązania, instytucje bądź procedury; 2) funkcji jakie dane rozwiązania (instytucje, procedury) mają spełniać albo spełniają $\mathrm{w}$ ramach systemu prawnego i -

35 Szerzej na ten temat zob. M. Borski, R. Glajcar, B. Przywora, Postępowanie ustawodawcze w Polsce. Prawo, zwyczaje i praktyka, Sosnowiec - Katowice - Częstochowa 2015, s. 80 i nast.

${ }^{36}$ L. Nowak, Próba metodologicznej charakterystyki prawoznawstwa, Poznań 1968, s. 77.

37 H. Rot, Wartości proceduralne..., s. 129 i nast. 
szerzej - systemu politycznego; i w końcu 3) instrumentów jakie wprowadzono (bądź właśnie nie wprowadzono choć należało tego oczekiwać), aby dany cel i skorelowane $\mathrm{z}$ nim funkcje $\mathrm{w}$ możliwie maksymalny sposób zrealizować ${ }^{38}$. Chodzi więc, innymi słowy mówiąc, o racjonalizację uwzgledniającą płaszczyznę teleologiczną, funkcjonalną i instrumentalną. Konstruując $w$ przepisach regulaminowych (a $\mathrm{w}$ idealnym stanie rzeczy w przyszłej ustawie o tworzeniu prawa ${ }^{39}$ ) poszczególne rozwiązania proceduralne należy korelować wskazane wyżej trzy płaszczyzny i tak budować nowe rozwiązania, ewentualnie modyfikować istniejące, aby osiągnąć efekt możliwie daleko posuniętej maksymalizacji wszystkich trzech płaszczyzn (aspektów) racjonalności ${ }^{40}$. Tytułem przykładu można wskazać rozgraniczenie, na poziomie konstytucyjnym, różnych rodzajów ustaw. Z Konstytucji da się bowiem wyraźnie wyprowadzić różne (odrębne) kategorie (rodzaje) ustaw albo na podstawie kryterium formalnego (sposobu dochodzenia danej ustawy do skutku) albo kryterium materialnego (zakresu przedmiotowego danej ustawy), przy czym oba kryteria są (i powinny być) ze sobą łączone (czego przykładem jest ustawa budżetowa), ale $\mathrm{w}$ takich przypadkach i tak najczęściej jedno z kryteriów uzyskuje status dominujący. Obok ustawy „zwykłej”, która dochodzi do skutku według „normalnej” procedury ustawodawczej, określonej w sekwencji art. 118-122 Konstytucji, wskazać można w związku z tym ustawę o zmianie Konstytucji, odrębnie potraktowaną w art. 235 Konstytucji; ustawę „pilną", której reżim proceduralny określa art. 123 Konstytucji; ustawę wyrażającą zgodę na ratyfikację umowy międzynarodowej (art. 89 Konstytucji), zwaną popularnie ustawą ratyfikacyjną bądź akceptującą; ustawę budżetową i powiązaną z nią ustawę o prowizorium budżetowym (art. 219 Konstytucji); czy w końcu tzw. ustawę „wyznaniową” (przewidzianą w art. 25 ust. 5 Konstytucji) ${ }^{41}$.

${ }^{38}$ Szerzej na temat postulatów racjonalnego tworzenia prawa zob. J Wróblewski, Teoria racjonalnego tworzenia prawa..., s. 132 i nast.

${ }^{39}$ Której powstanie jest od bez mała czterdziestu lat postulatem doktryny prawa. Szerzej na ten temat zob.: J. Wróblewski, Ustawa o tworzeniu prawa a pojęcie prawa i prawoznawstwa, „Państwo i Prawo” 1977, nr 8/9, s. 17 i nast.; S. Wronkowska, J. Wróblewski, Projekt ustawy o tworzeniu prawa, „Państwo i Prawo” 1987, nr 6, s. 3 i nast.; S. Wronkowska, Z historii ustawy o tworzeniu prawa, [w:] M. Kłodawski, A. Witorska, M. Lachowski (red.), Legislacja czasu przemian. Przemiany w legislacji. Księga jubileuszowa na XX-lecie Polskiego Towarzystwa Legislacji, Warszawa 2016, s. 210 i nast.

${ }^{40}$ Por. Z. Ziembiński, Problemy podstawowe..., s. 388 i nast.

${ }^{41} \mathrm{O}$ rozmaitych wariantach ustaw występujących na gruncie polskiego porządku konstytucyjnego zob. szerzej L. Garlicki, M. Zubik, Ustawa w systemie źródeł prawa, [w:] A. Szmyt (red.), Konstytucyjny system źródet prawa w praktyce, Warszawa 2005, s. 46 i nast. 
Regulamin Sejmu, w oparciu o art. 112 Konstytucji i odesłaną w nim do unormowania regulaminowego, materię regulaminu, jaką jest "porządek prac Sejmu" rzeczywiście dokonał rozgraniczenia procedur na okoliczność przyjmowania różnych ustaw. Regulamin Sejmu, choć nie ma ku temu podstaw w samej Konstytucji (aczkolwiek jest to jak najbardziej dopuszczalne), wyodrębnił dodatkowo kategorię ustaw kodeksowych (kodeksów) $^{42}$. Zwraca jednak uwagę, że nie wszystkie konstytucyjnie wyodrębnione kategorie ustaw mają swój odrębny, specyficzny tryb postępowania, mimo że logika niektórych z nich takiego odrębnego trybu co najmniej oczekuje, jeśli wręcz nie wymaga. W innych zaś przypadkach procedura dochodzenia odrębnych, innych niż ustawy zwykłe ustaw jest - jak się zdaje - zbyt słabo zaznaczona albo nie wykorzystuje potencjału odmienności danej kategorii ustawy. Warto więc przypomnieć, że Regulamin Sejmu, choć są ku temu wyraźne podstawy w Konstytucji RP, nie wprowadza (a powinien) dwóch szczególnych postępowań ustawodawczych. Chodzi mianowicie o postępowanie ratyfikacyjne, prowadzone na podstawie dyspozycji przepisu art. 89 Konstytucji i o postępowanie w sprawie dojścia do skutku tzw. ustawy wyznaniowej z art. 25 ust. 5 Konstytucji. W obu przypadkach szczególnie cel i funkcje ustanowienia odrębnej kategorii ustaw przemawiają za ustanoweniem (w Regulaminie Sejmu) odrębnych trybów ustawodawczych, tj. trybu ratyfikacyjnego i odpowiednio - trybu wyznaniowego. W pierwszym przypadku (tj. trybu ratyfikacyjnego) należałoby wyraźnie zastrzec, że inicjatywa ustawodawcza w sprawie przedłożenia Sejmowi projektu ustawy akceptującej należy wyłącznie do Rady Ministrów (jako organu prowadzącego politykę międzynarodową i zawierającego umowy międzynarodowe). W konsekwencji inicjatywa ustawodawcza innych podmiotów wymienionych w art. 118 Konstytucji powinna być $\mathrm{w}$ tym przypadku regulaminowo wyłączona, tym bardziej, że wyłączenie takie, choć tylko tacite, czyni zresztą sama Konstytucja. Należałoby je jednak przeprowadzić w sposób wyraźny a nie tylko dorozumiany. Innym elementem zróżnicowania tryby ratyfikacyjnego powinno być ograniczenie możliwości zgłaszania poprawek, tym bardziej, że treść takiej ustawy jest wyjątkowo lakoniczna. Przypomnieć

${ }^{42}$ Tworząc odrębne reżimy proceduralne w przepisach regulaminowych parlament, z jednej strony realizuje swoje podstawowe zadanie, jakim jest stanowienie prawa, $\mathrm{z}$ drugiej, w prawidłowy sposób określa zasady proceduralne i prakseologiczne, które muszą uwzględniać także materię regulowaną przez parlament. Szerzej na ten temat zob. A. Gwidż, Zagadnienia parlamentaryzmu w Polsce Ludowej, Warszawa 1972, s. 100 i nast. 
się godzi, że ustawa ratyfikacyjna składa się najczęściej zaledwie z dwóch przepisów, tj. przepisu akceptującego (czyli zawierającego zgodę na ratyfikację przez Prezydenta konkretnej umowy) oraz przepisu temporalnego (określającego moment wejścia ustawy w życie). Z tych względów autor Regulaminu Sejmu powinien również, działając racjonalnie, skrępować prawo wnoszenia poprawek wyłącznie do pewnego etapu prac legislacyjnych (w stanie de lege lata nie może być mowy o całkowitym wyłączeniu tego prawa z racji jego konstytucjonalizacji - por. art. 119 ust. 2 Konstytucji). To samo odnosi się do pożądanego (choć pod rządami obecnego przepisu art. 119 Konstytucji) niemożliwego do wyeliminowania na poziomie regulaminowym ograniczenia ilości czytań w przypadku ustawy ratyfikacyjnej. $Z$ racjonalnego punktu widzenia nie ma bowiem najmniejszego sensu procedować $\mathrm{w}$ trzech czytaniach nad dwuartykułową ustawą. Przykład ten potwierdza nota bene już wcześniej postawioną tezę o zbyt daleko idącej - jak się zdaje - ingerencji Konstytucji w materię regulaminową. Wydaje się, że podniesienie do rangi przepisu konstytucyjnego zasady trzech czytań (art. 119 ust. 1 Konstytucji) nie jest do końca zasadne i nadmiernie usztywnia proces ustawodawczy, co dotyczy zwłaszcza tych przypadków, kiedy takie usztywnienie jest zupełnie zbędne (to samo dotyczy również dyspozycji przepisu art. 119 ust. 2 Konstytucji konstytucjonalizującego zasady zgłaszania poprawek na etapie prac sejmowych).

Regulamin Sejmu, co należy uznać za swoiste zaniechanie legislacyjne, nie wyodrębnia również osobnego reżimu proceduralnego odnoszonego do tzw. ustawy „wyznaniowej” (co jest tym bardziej naganne, że Konstytucja obowiązuje już 18 lat). Tymczasem dla wprowadzenia odrębnego "postępowania wyznaniowego" istnieją mocne, konstytucyjne podstawy i wymóg jego wprowadzania postuluje od lat nauka prawa wyznaniowego (rzadziej, choć także konstytucyjnego) ${ }^{43}$. Przypomnieć się więc godzi, że kategoria ustaw wyznaniowych jest w polskim systemie prawa substytutem konkordatu, a dzięki temu formą gwarantowania innym niż Kościół katolicki kościołom i związkom wyznaniowym poszanowania zasady równouprawnienia (art. 25 ust. 1 Konstytucji). Chodzi generalnie o to żeby, podobnie jak to ma miejsce w przypadku umowy międzynarodowej mającej zastosowanie wobec Kościoła katolickiego, zagwarantować innym kościołom i związkom wyznaniowym poszanowanie zasady bila-

${ }^{43}$ Por. M. Olszówka, Ustawy wyznaniowe. Art. 25 ust. 5 Konstytucji RP. Próba interpretacji, Warszawa 2010, s. 66 i nast. 
teralizmu (art. 25 ust. 4 i 5 Konstytucji). Jej celem jest umowne określenie treści aktu prawnego regulującego stosunki państwa z danym związkiem wyznaniowym i wykluczenie możliwości jednostronnego (przez państwo) narzucenia pewnych rozstrzygnięć legislacyjnych. Żeby osiagnnąć ten pożądany stan rzeczy Konstytucja ustanowiła specjalny tryb umowny zawierania odpowiednich porozumień z władzami poszczególnych kościołów i innych związków wyznaniowych, a następnie ich transformowania w ustawę (bo tylko ustawa, a nie partykularna umowa ma moc prawa powszechnie obowiązującego). W rezultacie, Konstytucja przewiduje, że jedna ze stron tej umowy, która posiada inicjatywę ustawodawczą czyli Rada Ministrów, przedkłada Sejmowi projekt ustawy, który de facto ma być treściowym odpowiednikiem wcześniej zawartej umowy z władzami danego związku wyznaniowego. Rolą Sejmu, co wynika z logiki procedur określonych w art. 25 ust. 4 i 5 Konstytucji, jest więc jedynie akceptacja danej umowy (podobnie jak w przypadku konkordatu) i jej przekształcenie $\mathrm{w}$ prawo powszechnie obowiązujące tj. ustawę. $\mathrm{W}$ efekcie, stosowne do założonej w Konstytucji procedury postępowanie ustawodawcze (regulaminowo zdefiniowane) powinno przewidywać przynajmniej dwie rzeczy obligatoryjne i zarazem odrębne $\mathrm{w}$ stosunku do postępowania $\mathrm{z}$ ustawą „zwykłą". Chodzi mianowicie po pierwsze o ograniczenie kręgu podmiotów inicjatywy ustawodawczej wyłącznie do Rady Ministrów (tj. strony negocjującej umowę z władzami związku wyznaniowego) oraz o ograniczenie możliwości zmiany treści ustawy w stosunku do wynegocjowanej wcześniej treści umowy, bo to z kolei stanowi dopiero gwarancję konstytucyjnie zadeklarowanej zasady bilateralizmu. Oczywiście w obecnym stanie konstytucyjnym nie jest możliwe, choć znowu wielce pożądane, ograniczenie liczby czytań ustawy wyznaniowej, bo ona znowu przypomina nieco ustawę akceptującą (czyli ustawę, w której bez zgody drugiej strony umowy nie jest możliwe wprowadzenie nowych, nieuzgodnionych wcześniej treści).

Wreszcie uwagi krytyczne należy zgłosić co do prawa wyodrębnionego, ale jak się zdaje, zupełnie niefunkcjonalnego postępowania z pilnymi projektami ustaw (których podstawą konstytucyjną jest art. 123 Konstytucji, a regulaminową sekwencja art. 71-80 Regulaminu Sejmu). Tryb pilny, co wypada przypomnieć, nie jest przy tym rozwiązaniem właściwym jedynie dla Polski. Można wręcz powiedzieć, że tego rodzaju postępowanie (najczęściej zwane "nagłym”) jest pewnym standardem w systemach realizujących parlamentarną formę rządów. Wynika to z sygnalizowa- 
nego już wcześniej preferencyjnego traktowania rządu w całym procesie ustawodawczym, ergo stwarzania mu ułatwień w forsowaniu własnych przedłożeń legislacyjnych. W Polsce jednak, jak się okazuje, tryb pilny jest co najwyżej nie najlepszą proteza, a nie efektywnym narzędziem ułatwiającym rządowi oddziaływanie legislacyjne na parlament. Trzeba to szczególnie mocno podkreślić, gdyż nie ma jednocześnie w Polsce, typowego dla większości państw europejskich ustawodawstwa dekretowego scedowanego na kolegialny organ egzekutywy. W rezultacie Rada Ministrów nie ma wystarczających środków prowadzenia polityki państwa w myśl wyżej przytoczonego stwierdzenia H. Portelliego, że rządzić to móc realizować własne koncepcje legislacyjne. Mamy więc do czynienia z sytuacją gdzie Rada Ministrów nie ma możliwości wydawania (choćby w ograniczonej postaci) rozporządzeń z mocą ustawy, a zarazem tryb pilny zupełnie nie spełnia pokładanych $\mathrm{w}$ nim nadziei. Jest tak dlatego, że tryb ten - na mocy samej Konstytucji - limituje proces ustawodawczy tam, gdzie jest on i tak z założenia ograniczony (tj. w Senacie i na poziomie Prezydenta RP). Tymczasem miejscem, gdzie proces ustawodawczy statystycznie trwa najdłużej i gdzie napotyka najwięcej barier jest Sejm, który konstytucyjnie w żaden sposób nie został „dotknięty” reżimem trybu pilnego. W konsekwencji przepisy Regulaminu Sejmu jako jedyne właściwie przyspieszenie prac z projektami ustaw pilnych ustanawiają po pierwsze brak konieczności dochowania siedmiodniowego terminu na przedstawienie projektu w pierwszym czytaniu, licząc od momentu doręczenia druku inicjatywy ustawodawczej posłom (art. art. 73 ust. 1 Konstytucji), po drugie wprowadzenie instruktażowego terminu $30 \mathrm{dni}$ na przygotowanie przez komisję sejmową odpowiedniego sprawozdania (art. 73 ust. 2 Konstytucji) oraz, po trzecie zasadę niepoddawania pod głosowanie w drugim czytaniu poprawki, która wcześniej nie została przedstawiona komisji w formie pisemnej (art. 76 ust. 3 Konstytucji). W rezultacie postępowanie z pilnymi projektami ustaw jest najczęściej i tak czaso- i pracochłonne, w związku z czym Rada Ministrów mając na uwadze małą skuteczność tego narzędzia legislacji, a jednocześnie jego wysoką rezonansowość i fakt, że pilny projekt ustawy jest zazwyczaj pretekstem dla wzmożonej aktywności opozycji parlamentarnej (która retorycznie pyta o powód przyspieszenia prac rządowych) najczęściej nie korzysta z tej możliwości przyspieszenia postepowania ustawodawczego. Wskazać przy tym trzeba, że znowu w dużej części nieefektywność trybu pilnego jest skutkiem konstytucjonalizacji zasady trzech czytań. W poprzednim stanie prawnym (na 
gruncie postanowień ustawy konstytucyjnej z dnia 17 października 1992 roku o wzajemnych stosunkach między władzą ustawodawczą i wykonawczą Rzeczypospolitej Polskiej oraz o samorządzie terytorialnym ${ }^{44}$, popularnie nazywaną "małą Konstytucją") regulaminową istotą trybu pilnego było ograniczenie liczby czytań z trzech (właściwych dla trybu „zwykłego") do dwóch. Dzisiaj to zasadnicze przyspieszenie prac sejmowych nie wchodzi w grę. Należy więc, postępując racjonalnie, poszukać innych możliwości przyznania Radzie Ministrów efektywnych narzędzi akcelerowania prac ustawodawczych w ramach trybu pilnego. Repertuar tych narzędzi jest tutaj co prawda ograniczony, ale mimo wszystko warty rozważenia. Utrzymując istniejącą dzisiaj zasadę niedochowania siedmiodniowego terminu potrzebnego do zaprezentowania projektu ustawy na pierwszym czytaniu oraz zasadę skrępowania komisji terminem maksymalnie 30-dniowym dla zaprezentowania sprawozdania, można jeszcze dodać np. wyłączenie w ogóle możliwości wnoszenia poprawek na etapie drugiego czytania (wówczas poprawki byłyby dopuszczalne jedynie $\mathrm{w}$ pierwszym czytaniu oraz $\mathrm{w}$ pracach komisyjnych poprzedzających drugie czytanie) albo - opcjonalnie - wprowadzenie rozwiązania uzależniającego możliwość skutecznego zgłoszenia poprawki (co odnosiłoby się i do pierwszego i - ewentualnie - do drugiego czytania) od wyrażenia na nią zgody przez Radę Ministrów, czyli inicjatora projektu ustawy, która dzięki temu zachowałaby kontrolę nad koncepcją regulacyjną projektu pilnego (jednocześnie nie ograniczałoby to praw posłów, bowiem ci mieliby zawsze możliwość wystąpienia z inicjatywą ustawodawczą w tej materii; uchwalenie ustawy zainicjowanej w trybie pilnym nie konsumuje bowiem $\mathrm{w}$ żaden razie prawa do wystąpienia $\mathrm{z}$ inicjatywą $\mathrm{w}$ tej samej czy podobnej materii przez inne podmioty). Tego rodzaju rozwiązanie wydaje się być szczególnie atrakcyjne, gdyż po pierwsze rzeczywiście dawałoby Radzie Ministrów sposobność pilotowania projektu pilnego, czyli z jakichś powodów ważnego dla rządu, po drugie zaś mogłoby być postrzegane jako niedoskonały co prawda, ale jednak substytut rządowego ustawodawstwa dekretowego (którego wprowadzenie wymaga bezwzględnie zmiany Konstytucji). Do rozważenia pozostaje również możliwość wprowadzania regulaminowego przepisu wyłączjącego w przypadku trybu pilnego, możliwość przekazania projektu ustawy po drugim czytaniu po-

${ }^{44}$ Ustawa konstytucyjna z dnia 17 października 1992 r. o wzajemnych stosunkach między władzą ustawodawczą i wykonawczą Rzeczypospolitej Polskiej oraz o samorządzie terytorialnym, Dz.U. Nr 84, poz. 426 z późn, zm. 
nownie do komisji w celu przygotowania dodatkowego sprawozdania. Da się jeszcze wprowadzić, w odniesieniu do trybu pilnego, jedno rozwiązanie, które może się okazać i efektowne i efektywne. Chodzi mianowicie o przemodelowanie trzeciego czytania i ustanowienie w tym przypadku ograniczonej formy głosowania nad ustawą ${ }^{45}$. Chodzi o to, że w ostatecznym głosowaniu nad przyjęciem ustawy zainicjowanej $w$ trybie pilnym Sejm mógłby głosować albo 1) nad odrzuceniem ustawy w całości, jeśli taki wniosek byłby złożony, albo 2) nad jej przyjęciem w wersji przedłożenia rządowego (co oznacza, że bez poprawek), albo wreszcie 3) nad jej przyjęciem $\mathrm{w}$ wersji zaproponowanej przez izbę $\mathrm{z}$ uwzględnieniem poprawek, ale głosowanych łącznie, a nie każda oddzielnie (co też miałoby swój sens, gdyż wprowadzenie poprawek en bloc, a nie w sposób wybiórczy pozwoliłoby zachować spójność ustawy).

À propos czytań proces ustawodawczy, na etapie prac sejmowych byłby z pewnością bardziej racjonalny, gdyby wprowadzić jeszcze jedno ciekawe rozwiązanie. Chodzi o uprawnienia komisji sejmowych na etapie pierwszego czytania. Jak wiadomo, pierwsze czytanie zgłoszonego projektu ustawy odbywa się alternatywnie albo na posiedzeniu Sejmu in pleno albo na posiedzeniu komisyjnym. O ile przy tym w razie czytania mającego miejsce na plenarnym posiedzeniu Sejmu można projekt odrzucić w całości (jeśli uzna się bezprzedmiotowość bądź niecelowość prowadzenia dalszych prac) , o tyle komisyjne pierwsze czytanie musi się zawsze, niezależnie od stanowiska posłów zakończyć skierowaniem projektu do dalszych prac sejmowych, a następnym momentem odrzucenia projektu jest dopiero finalne głosowanie na etapie trzeciego czytania. Oznacza to, że „niechciany" projekt ustawy w momencie, kiedy jego pierwsze czytanie odbyło się "na komisji”, musi przejść przez całą ścieżkę legislacyjna, aby definitywnie można go było odrzucić. Inną ewentualnością jest co najwyżej odłożenie ad calendas graecas projektu w komisji, co jednak, z proceduralnego punktu widzenia jest zawsze dyskusyjne. Powyższe rozwiązanie wzbudza zastrzeżenia zwłaszcza, jeśli uwzględni się jego ratio legis. Otóż historycznie rzecz biorąc komisyjne pierwsze czytanie było wyjątkiem, zaś regułą było pierwsze czytanie przeprowadzane na plenarnym posiedzeniu izby. W latach 90-tych XX wieku zasadę tę odwrócono, co miało przyspieszyć proces ustawodawczy. $W$ rezultacie komisyjne pierwsze czytanie stało się reguła, podczas gdy plenarne wyjątkiem odniesionym

\footnotetext{
${ }^{45}$ Por. Z. Jarosz, Postępowanie ustawodawcze...., s. 85 i nast.
} 
wprost do niektórych kategorii ustaw (np. budżetu, ustaw podatkowych czy ustawy o zmianie Konstytucji). Wspomniane odwrócenie było motywowane przede wszystkim chęcią przyspieszenia prac ustawodawczych. Optymistycznie zakładano, że to istotnie zracjonalizuje i zakceleruje proces legislacyjny. Niemniej pokładane nadzieje nie do końca udało się zrealizować, a to za sprawą dyspozycji przepisu art. 39 ust. 2 Regulaminu Sejmu. Artykuł ten expressis verbis przewiduje, że "pierwsze czytanie na posiedzeniu Sejmu kończy się skierowaniem projektu do komisji, chyba że Sejm w związku ze zgłoszonym wnioskiem odrzuci projekt w całości". A contrario oznacza to, że prawem odrzucenia projektu ustawy już na początku, bo w pierwszym czytaniu nie dysponuje komisja. Wydaje się, że racjonalnie skrojona procedura ustawodawcza, biorąc pod uwagę ratio legis przekazania komisjom projektu ustawy do pierwszego czytania, powinna jednak - mimo wszystko - dopuszczać możliwość odrzucenia projektu także przez komisję. Godzi się w tym miejscu przypomnieć, że są państwa (np. Hiszpania ${ }^{46}$, Włochy ${ }^{47}$ ), w których uprawnienia komisji idą nawet dalej, gdyż mogą one uchwalać ustawy, zastępując w tym zakresie plena izb, zgodnie zresztą ze znanym założeniem, że komisje to nic innego jak „miniatury parlamentów”. Zgłoszona tutaj możliwość aż tak daleko nie idzie (tym bardziej, że Konstytucja wprost stwierdza, że to Sejm uchwala ustawy - por. art. 120 Konstytucji, co jednak - wbrew pozorom nie eliminuje wcale możliwości decydowania w tej sprawie przez organy Sejmu, gdyż dla nich i dla określenia ich roli legislacyjnej przewidziana jest pełnia władzy regulacyjnej regulaminu Sejmu, stosownie do postanowień art. 112 Konstytucji). Niemniej można chyba dopuścić sytuację przyznania komisjom prawa odrzucenia projektu już w pierwszym czytaniu, analogicznie jak to ma miejsce w Sejmie in pleno. Oczywiście pojawia się w tym miejscu pytanie o konstytucyjną dopuszczalność tego rodzaju rozwiązania. Wydaje się jednak, że mimo wszystko obowiązująca Konstytucja nie stwarza wyraźnych przeszkód w jego ustanowieniu. Niemniej z racji ostrożności procesowej, Regulamin Sejmu mógłby dopuścić i to byłoby już bez żadnych wątpliwości zgodne z Konstytucja że ewentualna decyzja komisji w sprawie odrzucenia zgłoszonego projektu ustawy nie byłaby ostateczną i albo wymagałaby zawsze odpowiedniej zgody izby in pleno

46 T. Mołdawa, Procedura legislacyjna w Hiszpanii, "Przegląd Sejmowy” 1993, nr 4, s. 71,72 .

47 Z. Witkowski, Postepowanie ustawodawcze we Wtoszech, [w:] E. Zwierzchowski (red.), Postępowanie ustawodawcze, Warszawa 1993, s. 249 i nast. 
albo - opcjonalnie - mogłaby być wzruszona na wniosek zgłoszony przez kwantytatywnie określoną grupę posłów (np. co najmniej 15 albo, co byłoby chyba jeszcze lepsze, przez dwukrotność liczby posłów niezbędnych do założenia klubu poselskiego, co eliminowałoby obstrukcję parlamentarną ze strony najmniejszych klubów). Do pomyślenia byłaby również sytuacja, w której to nie Sejm, w każdym przypadku lub na wniosek złożony przez odpowiednią liczbę posłów, byłby władny odrzucić uchwałę komisji w sprawie odrzucenia projektu ustawy już w pierwszym czytaniu. Równie dobrze prawo takie można bowiem przyznać Prezydium Sejmu. Można by było ustanowić w związku z tym przepis regulaminowy, który dawałby Prezydium Sejmu możliwość uchylenia takiej uchwały komisji. Byłoby to rozwiązanie o tyle uzasadnione, że po pierwsze wzmacniałoby Prezydium (mocno zdewaluowane na skutek jego dekonstytucjonalizacji przeprowadzonej w 1997 r. i przyjętych w wyniku tego nowelizacji Regulaminu Sejmu), po drugie zaś byłoby formą wzmocnienia praw opozycji parlamentarnej, zawsze przecież - w jakiejś formie - reprezentowanej w Prezydium Sejmu ${ }^{48}$. Jak widać wariantów możliwego uczynienia procesu ustawodawczego bardziej racjonalnym jest co najmniej kilka i tylko od woli Sejmu zależy czy sięgnie po nie czy nie.

\section{Profesjonalizm procesu ustawodawczego}

Kolejnym postulatem mającym doprowadzić do pożądanej optymalizacji procesu legislacyjnego jest postulat, w myśl którego proces ustawodawczy powinien być bardziej profesjonalny ${ }^{49}$. Wskazuje się jak najbardziej słusznie zreszta, że profesjonalizm jest warunkiem sine qua non racjonalnego modelu tworzenia prawa ${ }^{50}$. Bez stworzenia warunków do właściwej selekcji, ustrukturyzowania i przekazywania fachowej, moż-

48 A której to opozycji formalnie nie ma przewidzianej w przepisach regulaminowych, co uznać wypada za istotny mankament tych przepisów. Dzisiaj bowiem już pewnym standardem jest nie tylko uznania w praktyce działania opozycji ale również jej prawna instytucjonalizacja (Jurydyzacja). Szerzej na ten temat zob.: S. Bożyk, Opozycja parlamentarna w Sejmie RP, Warszawa 2005, s. 56 i nast.; S. Bożyk, Prawnoustrojowy status opozycji parlamentarnej w Sejmie Rzeczypospolitej Polskiej, Białystok 2005, s. 178 i nast.

${ }^{49}$ J. Karp, J. Szymanek, Profesjonalizacja parlamentarnych prac ustawodawczych, "Przegląd Sejmowy" 2009, nr 5, s. 111 i nast.

${ }^{50}$ H. Rot, Wartości proceduralne..., s. 81 i nast. 
liwie pełnej, obiektywnej i aktualnej wiedzy nie ma w ogóle mowy o racjonalnym ustawodawcy, jak i szerzej o racjonalnym sposobie podejmowania jakichkolwiek decyzji ${ }^{51}$. Dysponowanie merytoryczną wiedzą (informacją) na określony temat jest wobec tego warunkiem progowym racjonalnego działania, w tym również działania, którego skutkiem ma być ustanowienie normy prawnej (zwłaszcza o randze ustawy) ${ }^{52}$. Co więcej, waga czynnika profesjonalnego (merytorycznego) sukcesywnie wzrasta ${ }^{53}$. Jest to funkcją m.in. inflacji prawa i obejmowania gorsetem regulacyjnym coraz to nowych obszarów życia; coraz większego skomplikowania i zdetalizowania materii ustawowej; naturalnego skądinąd rozwoju stanu wiedzy oraz informacji na określony temat; ogólnego postępu cywilizacyjnego we wszystkich niemal sferach życica człowieka. Dlatego istnieje potrzeba tworzenia rozbudowanego, profesjonalnie działającego zaplecza eksperckiego, obejmującego nie tylko parlament (Sejm i Senat) ale i wszystkie pozostałe podmioty zaangażowane (na rożnych etapach i z różną mocą decyzyjną) w proces prawotwórczy (Rada Ministrów i poszczególne ministerstwa, Prezydent RP, Trybunał Konstytucyjny $)^{54}$. Niemniej uwzględniając założenia praktyki tworzenia prawa w ramach systemu parlamentarnego, kluczowe znaczenie dla należytej fachowości procesu ustawodawczego mają właściwe służby parlamentarne ${ }^{55}$ oraz rządowe ${ }^{56}$.

Pożądany profesjonalizm prac ustawodawczych wymaga patrzenia na proces ustawodawczy jak na szczególnego rodzaju proces informacyjny ${ }^{57}$, w którym dochodzi do pojawiania się całej gamy informacji i ta-

${ }^{51}$ Szerzej na ten temat zob. S. Zawadzki, J. Mazur, R. Piotrowski, Kryteria optymalizacji decyzji państwowych, [w:] A. Bodnar, W. J. Szczepański (red.), Decyzje polityczne w systemach społecznych, Warszawa 1987, s. 110 i nast.

52 Por. D. Merten, Ustawodawstwo w państwie prawnym. Możliwości, wyzwania, zobowiazania, [w:] H. Suchocka (red.), Tworzenia prawa w demokratycznym państwie prawa, Warszawa 1992, s. 31 i nast.

${ }^{53}$ Z. Bauman, Prawodawcy i tłumacze, Warszawa 1998, s. 61 i nast.

${ }^{54}$ Por. J. Szymanek, Udział czynnika eksperckiego w procesie ustawodawczym, [w:] W. Brzozowski, A. Krzywoń (red.), Leges ab omnibus..., s. 419 i nast.

55 Parlamentarne dlatego, że to do parlamentów należy kompetencja prawotwórcza, co oznacza, że decydenci parlamentarni muszą dysponować możliwie pełną, fachową i we właściwy sposób ustrukturyzowaną wiedzą na dany temat.

${ }^{56}$ Rządowe dlatego, że w systemie parlamentarnym to rząd jest podmiotem szczególnym w całym procesie ustawodawczym, choćby dlatego, że to rząd (gabinet) w praktyce jest zasadniczym wykonawcą inicjatywy ustawodawczej, która choćby z tego powodu powinna być przygotowana możliwie merytorycznie i w sposób kompletny.

57 Por. E. Kustra, Proces ustawodawczy jako proces informacyjny, [w:] K. Grajewski, J. Warylewski (red.), Informacja prawna a prawa obywateli, Sopot 2006, s. 119 i nast. 
kiego zorganizowania kanałów jej przepływu, aby pozwoliło ono koniec końców podjąć możliwe najlepszą decyzją prawodawczą ${ }^{58}$. Postrzeganie procesu legislacyjnego jako szczególnej postaci procesu informacyjnego można opisać językiem analizy systemowej, gdzie na wejściu do systemu pojawia się inicjatywa ustawodawcza, czyli jakaś informacja. Następnie wewnątrz tego systemu ( $w$ ramach procesu ustawodawczego przebiegającego $\mathrm{w}$ parlamencie) pojawia się wiele innych informacji (pod postacią opinii, ekspertyz, raportów, stanowisk posłów, komisji oraz podmiotów opiniujących), w wyniku czego następuje konwersja czyli wymiana wielu, różnych informacji i ich przekształcenie, a w rezultacie wygenerowanie na tzw. wyjściu z systemu komunikatu zwrotnego (informacji), którym w tym przypadku - jest ostatecznie przyjętą ustawą ${ }^{59}$. Oczywiście proces konwersji jest najważniejszym elementem postrzegania legislacji jako procesu komunikacyjnego ${ }^{60}$. Niemniej zaznaczyć trzeba, że dysponowanie fachową wiedzą nie ogranicza się jedynie do stadium parlamentarnego prac ustawodawczych. Ekspercka diagnoza stanu rzeczy jest wszakże niezbędna już na wejściu do systemu (parlamentu), w odniesieniu do inicjatywy ustawodawczej, która także wymaga niezbędnych prac studyjno-ekspercko-przygotowawczych, jak i po wyjściu z systemu, gdzie potrzebna jest również merytoryczna ocena skutków regulacji ( $\mathrm{zw}$. OSR ex post). Niemniej węzłowym punktem eksperckiego zaangażowania $\mathrm{w}$ proces ustawodawczy jest niewątpliwie stadium prac parlamentarnych ${ }^{61}$.

Zgodnie zaznacza się, że to stadium jest kluczowe zarówno jeśli idzie o uzgodnienia polityczne, jak i merytoryczne i w dużym stopniu decyduje o powodzeniu uruchomianych prac nad ustawą. Wynika to zresztą z oczywistego faktu, że to parlament jest dysponentem władzy ustawodawczej i to on podejmuje ostateczne rozstrzygnięcia dotyczące dojścia bądź nie dojścia ustawy do skutku. Stąd bierze się waga odpowiedniego oprzyrządowania eksperckiego na etapie parlamentarnych prac ustawodawczych oraz wyraźnie dostrzegalna dwutorowość wykorzystywanej wiedzy i informacji. Wiedza ta musi być bowiem w pełni fachowa, moż-

58 Por. P. Radziewicz, Doradztwo naukowe w pracach Sejmu, „Przegląd Sejmowy” 2013, nr 5, s. 33 i nast.

59 Szerzej na temat modelu analizy systemowej zob. T. Langer, Amerykańska wersja analizy systemowej w nauce o państwie, Warszawa 1977, s. 155 i nast. Zob. również A. Dudzińska, System zamknięty. Socjologiczna analiza procesu legislacyjnego, Warszawa 2015, s. 28 i nast.

${ }^{60}$ Por. W. Cyrul, Wptyw procesów komunikacyjnych..., s. 234 i nast.

${ }^{61}$ A. Szymt, Opiniodawczo-doradcza obstuga sejmowych prac ustawodawczych, [w:] M. Kudej (red.), W kręgu zagadnień konstytucyjnych, Katowice 1999, s. 154 i nast. 
liwie kompletna i obiektywna, z jednej strony, z drugiej zaś powinna być wiedza, którą warunkuje zajmowane miejsce w przestrzeni rywalizacji polityczno-partyjnej. Nie sposób bowiem ignorować politycznego kontekstu prac parlamentarnych ${ }^{62}$, stąd wskazuje się, że decydenci parlamentarni żeby $\mathrm{w}$ racjonalny sposób mogli podejmować decyzję legislacyjne, powinni dysponować dwojakiego rodzaju wiedzą i informacją. Po pierwsze muszą oni dysponować wiedzą w miarę obiektywną pełną, naświetlającą badany problem z różnych punktów widzenia, a przez to niezbędną do podjęcia rozstrzygnięć merytorycznych. Po drugie zaś muszą oni sięgać również po wiedzę wykorzystywaną na użytek przetargów politycznych, jakie w każdym paramencie maja, bo i muszą mieć miejsce ${ }^{63}$. W efekcie, na etapie prac parlamentarnych dochodzi (powinno dochodzić) do wyraźnego rozdwojenia zaplecza eksperckiego. Obejmować ono powinno jak najbardziej merytoryczne, obiektywne, fachowe i możliwie zróżnicowane pod względem przedmiotowym zaplecze pozostające w dyspozycji parlamentu jako takiego oraz zaplecze frakcyjne, pozostające na usługach klubów parlamentarnych, które oprócz koniecznego elementu merytorycznej oceny przedłożeń legislacyjnych wnoszą również niezbędny w parlamentarnym procesie decyzyjnym element oceny politycznej (wartościującej). Tego ostatniego nie da się zignorować i pominąć w procesie ustawodawczym. Nie zawsze zresztą musi on mieć - jak się sądzi - pejoratywne znaczenie. Często element polityczny w ocenie eksperckiej wnosi bowiem istotne treści do podejmowanych rozstrzygnięć merytorycznych, a w finalnym kształcie jest zawsze czynnikiem decydującym o dojściu ustawy do skutku i jej konkretnym kształcie.

Optymalny proces dochodzenia ustawy do skutku, na etapie prac parlamentarnych, winien więc obejmować zarówno wiedzę ekspercką uwolnioną od politycznych wpływów, presji i nacisków, jak i wiedzą zabarwioną elementem polityczno-partyjnego zaangażowania (wartościowania) ${ }^{64}$. Dopiero łączne ujęciu obu aspektów oceny eksperckiej stwarza należytą rękojmię rzetelności procesu ustawodawczego i jego pełnej racjonalności (w tym dysponowania rozległą i wielowątkową wiedzą), a co za tym idzie i profesjonalizmu. Odrębność i wielosektorowość eksperckiego oprzyrzą-

${ }^{62}$ Szerzej na ten temat zob. J. Szymanek, Funkcja ustawodawcza parlamentu (w ujęciu analizy politologicznej), „Przegląd Legislacyjny” 2006, nr 2, s. 35 i nast.

${ }_{63}$ Por. R. Stohanzl, W sprawie organizacji naukowych stużb doradczych parlamentu, [w:] H. Suchocka (red.), Tworzenie prawa w demokratycznym państwie prawa..., s. 203 i nast.

${ }^{64}$ Por. J. Szymanek, Udział czynnika eksperckiego...., s. 419 i nast. 
dowania parlamentarnych prac ustawodawczych jest więc jednym z podstawowych warunków racjonalnego procesu ustawodawczego. Podobnie jest z oddzielnością i niezależnością parlamentarnego zaplecza eksperckiego (w jego obu pionach tj. merytorycznym i politycznym) od zaplecza rządowego. Istnienie różnych źródeł pozyskiwania wiedzy i informacji, ergo różnych form eksperckiej obsługi prac ustawodawczych jest wszak co zrozumiałe - jednym z warunków minimum racjonalności rzeczowej, czyli dysponowania wiedzą obiektywną jako podstawową przesłanką podejmowania decyzji legislacyjnych. W konsekwencji poseł powinien dysponować tzw. „,informacją merytoryczną”, czyli obiektywną, możliwie pełną i aktualną informacją o stanie spraw będących przedmiotem postępowania legislacyjnego, jak i tzw. „informacją wartościującą”, czyli oceną danej sprawy uwzględniającą szerokie spectrum spojrzenia politycznego, ideologicznego i światopoglądowego. O ile przy tym pierwszy rodzaj informacji powinna zapewniać i dostarczać Kancelaria Sejmu (pracująca na użytek wszystkich posłów bez podziałów, sympatii czy antypatii politycznych), o tyle drugi rodzaj informacji, ze swej istoty, powinien być zabezpieczony przez kluby i koła poselskie (frakcje parlamentarne), które winny wobec tego posiadać zdolności przede wszystkim budżetowe do zapewnienia przynajmniej minimalnego poziomu obsługi eksperckiej ${ }^{65}$.

Prawidłowo zorganizowane oprzyrządowanie eksperckie, mające zastosowanie na użytek parlamentarnych prac nad ustawą powinno jeszcze obejmować jeden aspekt związany z właściwym ulokowaniem ośrodka eksperckiego. Chodzi mianowicie o to, aby ośrodek, szczególnie w jego pionie generującym „informację merytoryczną", nie był ośrodkiem wyłącznie wewnątrzparlamentarnym. Ekspert zaangażowany w proces ustawodawczy powinien bowiem pochodzić zarówno z Kancelarii Sejmu i właściwej komórki odpowiedzialnej za informację (tj. Biura Analiz Sejmowych ${ }^{66}$ ), jak

${ }^{65}$ P. Radziewicz, Doradztwo naukowe w pracach Sejmu..., s. 46 i nast.

${ }^{66}$ Biuro Analiz Sejmowych, wcześniej Biuro Studiów i Ekspertyz to jednostka organizacyjna Kancelarii Sejmu istniejąca od 1990 r. Do jej zadań należy: opiniowanie projektów aktów prawnych, podczas prac legislacyjnych, dostarczanie informacji oraz opracowywanie opinii na potrzeby posłów, organów Sejmu, szefa Kancelarii Sejmu i jego zastępców, wykonywanie ekspertyz dotyczących szeroko rozumianych zagadnień prawnych, politycznych i ekonomicznych oraz realizacja innych zadań zleconych przez Sejm. W Biurze powołany jest też zespół zajmujący się bezpośrednią współpracą z posłami i organami Sejmu, który pełni stały dyżur w tzw. starym domu poselskim, udzielając na bieżąco odpowiedzi na pytania oraz udostępniając materiały opracowane w Biurze. Por. Słownik wiedzy o Sejmie, A. Preisner (red.), Warszawa 2001, s. 17-18. 
i spoza Kancelarii i szerzej, spoza Sejmu ${ }^{67}$. Racjonalna a przede wszystkim profesjonalnie przygotowana "informacja merytoryczna” powinna być więc znowu dwutorowa, tzn. obejmować „informację merytoryczną” wewnętrzną (a zatem przygotowaną w ramach Kancelarii Sejmu), jak i „,informację merytoryczną" pochodzącą z zewnątrz.

W efekcie optymalny model eksperckiej obsługi parlamentarnych prac zmierzających do uchwalenia ustawy powinien być modelem " $2 \times 2 ", \mathrm{tj}$. zakładać „informację merytoryczną” i „informację wartościującą”, a obok tego „informację wewnętrzną” i „informację zewnętrzną” .Zaznaczyć trzeba przy tym, że ewentualna egzageracja informacji nie jest (nie powinna być) problemem. Doświadczenia procesu ustawodawczego wskazują bowiem, że problemem jest zawsze nie nadmiar a niedobór informacji, ewentualnie jej selektywność, którą minimalizuje - przynajmniej w jakimś stopniu - wielość źródeł pozyskiwania informacji (wiedzy) ${ }^{68}$. Dlatego tak ważne jest zapewnienie maksymalnej dostępności informacji oraz jej obiegu wewnątrzparlamentarnego.

Z tego punktu widzenia należy jeszcze wskazać na mankamenty dotychczasowej praktyki, które to wzięte razem składają się na obraz mniej profesjonalnych, a przez to i mniej racjonalnych działań ustawodawczych (a niekiedy również działań budzących wątpliwości na gruncie etyki). Chodzi tutaj przede wszystkim o: 1) zbyt rzadkie odwoływanie się do ekspertyzy zewnętrznej; 2) zbyt rzadkie odwoływanie się do „informacji wartościującej" jak i dyskredytowanie tego rodzaju informacji jakoby zupełnie nieprzydatnej dla procesu legislacyjnego; 3) często spotykana niekonkluzywność ekspertyzy czy opinii, co ma miejsce szczególnie w odniesieniu do „informacji merytorycznej”69; 4) niejasne powiaząnia formalne, a zwłaszcza nieformalne między Sejmem (posłem) a osobami z zewnątrz wykonującymi ekspertyzy i w rezultacie 5) występująca niekiedy zamiana ról eksperta i lobbysty; 6) korzystanie z ekspertów (fachowców) polifonicznych, tj. takich którzy znają się na wszystkim i są w stanie napisać każdą ekspertyzę, tzn. na dowolny temat i z dowolnymi konkluzjami,

${ }^{67}$ Dzięki temu realizowany jest istotny dla całego procesu legislacyjnego postulat obiektywności prawotwórczej. Por. J. Szymanek, Udział czynnika eksperckiego...., s. 435 i nast.

${ }_{68}$ Por. H. Rot, Uwarunkowania i wartości..., s. 123.

${ }^{69}$ Przy czym taka niekonkluzywność występuje zarówno w ekspertyzach wewnętrznych, jak i w ekspertyzach zewnętrznych, w obu przypadkach czyniąc takie ekspertyzy zupełnie nieprzydatnymi dla decydentów. 
a często też z wnioskiem pisanym w celu uzyskania przychylności bądź zadowolenia osoby, która ekspertyzę zamawiała ( $\mathrm{zw}$. wniosek na zamówienie). Jako szczególnie nagannie należy ocenić cztery ostatnie wymienione praktyki i zjawiska. Po pierwsze nie może być tak, że ekspert (z założenia dysponujący fachową wiedzą na dany temat) nie umie (albo co gorsza nie chce) udzielić jednoznacznej konkluzji. Opinia eksperta jest potrzebna po to właśnie, żeby taką konkluzję sformułować. Jeśli więc nie daje ona jednoznacznego rozstrzygnięcia (nawet jeśli ekspert się myli albo konkluzja nie jest zgodna z oczekiwaniami podmiotu zamawiającego opinię) to ekspertyza nie spełnia swojej prakseologicznej funkcji i jest, zupełnie nieprzydatna. Rozważenia w takiej sytuacji wymagałoby wprowadzenie możliwości wypłaty jedynie częściowego wynagrodzenia (np. w wysokości 25\% kwoty bazowej). Po drugie, nie można akceptować rozmaitego rodzaju, najczęściej nieformalnych powiązań między zewnętrznymi ekspertami a Sejmem bądź parlamentarzystami. Rzeczą naganną jest np. korzystanie przez Kancelarię Sejmu czy Kancelarię Senatu z usług wybranych, najczęściej stale jednych i tych samych prywatnych kancelarii prawniczych bądź osób w nich zatrudnionych. Przypadki takich działań niestety się zdarzają i czasami przybierają taką postać, że niektóre kancelarie bądź eksperci stają się prawie że etatowymi usługodawcami Sejmu (Senatu). Po trzecie, ogół wskazanych wyżej zjawisk doprowadza często do sytuacji, w której mieszają się legislacyjne role, a ekspert „wchodzi w buty lobbysty" (jeszcze gorzej jest wówczas, kiedy lobbystą staje się sam parlamentarzysta). Zaznaczyć jednocześnie trzeba, że lobbing nie jest $\mathrm{w}$ żadnym razie zjawiskiem nagannym czy zasługującym na potępienie. Nagannym staje się on wówczas, kiedy dochodzi właśnie do sytuacji niejasnych, wątpliwych, mało przejrzystych i czytelnych i kiedy to osoby z założenia spełniające inne role (posła bądź eksperta) zamieniają się w lobbystę. Po czwarte w końcu, rzeczą naganną, a przynajmniej niewskazaną z profesjonalnego punktu widzenia jest korzystanie z usług ekspertów, którzy są w stanie napisać każdą ekspertyzę i poprzeć bądź odrzucić każdą propozycję legislacyjną, często stosując się do oczekiwań podmiotu zamawiającego opinię. Tutaj jednak dochodzimy do problemu tzw. etyki eksperta, której - jak dobrze widomo - nie da się w żaden prawny sposób narzucić ani wyegzekwować.

Żeby z jednej strony wzmocnić dążenie do profesjonalizmu procesu ustawodawczego, z drugiej zaś wyeliminować wadliwą praktykę, można zasugerować kilka rozwiązań szczegółowych, przy czym większość 
z nich powinna się znaleźć w przepisach Statutu Kancelarii Sejmu, a niektóre mogą się znaleźć w regulaminie izby (w najgorszym razie w wytycznych sporządzonych przez Prezydium Sejmu jako organu regulaminowo odpowiedzialnego za ustalanie zasad obsługi eksperckiej).

Zaczynając od Regulaminu Sejmu, można pomyśleć o wprowadzeniu przepisu, który wprost dawałby klubom i kołom poselskim prawo prowadzenia ograniczonego zaplecza eksperckiego, wykorzystywanego na potrzeby sporządzania „informacji wartościującej”, co oczywiście wiązałoby się z wyodrębnieniem w budżecie Sejmu odpowiedniego funduszu eksperckiego. Z kolei w Statucie Kancelarii (bądź wytycznych Prezydium Sejmu) należałoby pomyśleć o wprowadzeniu takich m.in. rozwiązań jak: 1) wyraźnym rozróżnieniu eksperta wewnętrznego i zewnętrznego; 2) wprowadzeniu mechanizmu ustalającego listę ekspertów zewnętrznych, co zabezpieczałoby przed praktyką sięgania po ekspertów dobieranych na zasadzie koleżeńskiej czy towarzyskiej. Listę taką można by było co jakiś czas weryfikować, a jej akceptację można powierzyć np. Prezydium Sejmu (co zgodne by było z art. 12 Regulaminu Sejmu, który precyzując kompetencje Prezydium Sejmu powierza mu ustalanie zasad organizowania doradztwa naukowego na rzecz Sejmu i jego organów, powoływania doradców sejmowych oraz korzystania z opinii i ekspertyz); 3) wprowadzaniu mechanizmu weryfikującego poprawność opinii z punktu widzenia jej użyteczności prakseologicznej i ustanowieniu sankcji za ekspertyzy nie spełniające wymagań (w postaci np. wskazanego wcześniej procederu wypłaty jedynie $25 \%$ wynagrodzenia w sytuacji ekspertyzy bezkonkluzywnej); 4) wprowadzaniu wyraźnego zakazu instytucjonalnych powiazań Kancelarii Sejmu (Senatu) z prywatnymi kancelariami prawnymi. W sytuacjach bowiem, kiedy gros zadań powierza się prywatnym kancelariom prawniczym (przy czym nie chodzi tu jedynie o działania eksperckie ale również o działania stricte legislacyjne) to podważa się sens obecności Kancelarii Sejmu (Senatu), a obok tego rodzi się naturalne podejrzenie działać co najmniej quasi-lobbingowych.

Większa profesjonalizacja prac ustawodawczych powinna oznaczać jednak nie tylko wzmocnienie roli eksperta, ale także ewentualną zmianę tych przepisów, które dotyczą - generalnie rzecz ujmując - obiegu informacji ${ }^{70}$. Jak to już powiedziano wcześniej, proces ustawodawczy to przecież jedna z odmian procesu informacyjnego, a dysponowanie właściwą

\footnotetext{
${ }^{70}$ E. Kustra, Proces ustawodawczy jako proces informacyjny..., s. 120.
} 
informacją dobrze wyselekcjonowaną, ustrukturyzowaną wyjaśnioną, możliwie pełna, aktualną i fachową jest podstawą racjonalnie prowadzonego procesu tworzenia prawa. Dlatego też rozważyć trzeba korektę tych przepisów, które pozwalają Marszałkowi Sejmu np. dopuścić do nadania biegu projektom ustawy, których uzasadnienie nie spełnia określonych wymogów z art. 34 Regulaminu Sejmu. I tak np. korekty wymaga art. 34 ust. 7 Regulaminu Sejmu, który daje Marszałkowi Sejmu możliwość zwrócenia wnioskodawcy projektu ustawy lub uchwały, jeśli uzasadnienie do projektu nie odpowiada wymaganiom regulaminowym. Wydaje się, że $\mathrm{w}$ tym przypadku stosowny przepis powinien brzmieć nie - jak ma to miejsce obecnie - „Marszałek Sejmu może zwrócić wnioskodawcy” tylko „Marszałek Sejmu zwraca wnioskodawcy”. Postępowanie Marszałka Sejmu musi być tutaj jednoznaczne i nie może stwarzać marginesu dowolności. Istniejąca dzisiaj alternatywa działania Marszałka (który może zwrócić albo może nie zwrócić) stwarza ryzyko możliwości nadania biegu projektowi, który nie daje posłom pełnej informacji o powodach i celu jego zainicjowania, co kłóci się z wymogami profesjonalnie prowadzonego procesu legislacyjnego. $Z$ jeszcze dziwniejszym i niezrozumiałym, uwzględniając dyrektywę racjonalnego i profesjonalnego działania, stanem rzeczy mamy do czynienia w przypadku art. 34 ust. 8 Regulaminu Sejmu ${ }^{71}$. W tym przypadku wątpliwości Marszałka Sejmu co do zgodności projektu z prawem Unii Europejskiej albo zasadami techniki prawodawczej (ale przynajmniej nie wprost - z Konstytucją), jeśli zostaną podzielone przez Prezydium Sejmu dają Marszałkowi możliwość zwrócenia się do komisji ustawodawczej i w sytuacji, kiedy ta podzieli pogląd o niezgodności projektu z wzorcem i uzna go za niedopuszczalny, Marszałek Sejmu dostaje możliwość nienadania projektowi biegu ${ }^{72}$. W przepisie tym zwraca uwagę alternatywa niemalże każdego działania Marszałka Sejmu. Jedyny oblig dotyczy zasięgnięcia opinii Prezydium Sejmu (wymóg formalny), natomiast wszystkie pozostałe działania Marszałka są jedynie możliwością a nie koniecznością. W konsekwencji, co godzi w zasadę profesjonalizmu, art. 34 ust. 8 Regulaminu Sejmu dopuszcza do sytuacji, w której Marszałek nie podzieli zdania komisji ustawodawczej i nada bieg inicjatywie wywołującej uzasadnione wątpliwości prawne albo - jeszcze wcześniej - nie podzieli

${ }^{71}$ Szerzej na ten temat zob. A. Szmyt, Badanie dopuszczalności projektu ustawy w trybie art. 34 ust. 8 regulaminu Sejmu, „Przegląd Sejmowy” 2012, nr 5, s. 9 i nast.

${ }^{72}$ Szerzej na ten temat zob. K. Kubuj, Rola Marszałka Sejmu w postępowaniu ustawodawczym, „Przegląd Legislacyjny” 2004, nr 2, s. 12 i nast. 
opinii Prezydium Sejmu i nie zwróci się do komisji ustawodawczej o zajęcie przez nią stanowiska. Przepis art. 34 ust. 7 i ust. 8 Regulaminu Sejmu podważa profesjonalizm działania Sejmu. W pierwszym przypadku dlatego, że dopuszczają rozpoczęcie prac legislacyjnych w stosunku do ustawy, wobec której posłowie nie posiadają właściwej (kompletnej) wiedzy na dany temat, ergo nie są w stanie podjąć racjonalnej decyzji. W drugim przypadku dlatego, że dopuszczają do nadania biegu w stosunku do projektu, który wzbudza poważne wątpliwości prawne, co godzi nie tylko w fachowość pracy izb i jej organów ale również w zasadę zakazującą parlamentowi stanowienia prawa nielegalnego i niekonstytucyjnego ( $\mathrm{zw}$. negatywny obowiązek ustawodawcy zwykłego).

\section{Uspołecznienie procesu ustawodawczego}

Proces ustawodawczy powinien być również bardziej uspołeczniony $\mathrm{i}$ jest to następny postulat $\mathrm{w}$ zakresie korekt $\mathrm{w}$ istniejącym de lege lata stanie prawnym ${ }^{73}$. Jak wiemy, włączenie społeczeństwa $\mathrm{w}$ mechanizm dochodzenia ustawy do skutku jest przejawem uznania dla demokratycznego modelu prawotwórstwa ${ }^{74}$. Jego współczesną odsłoną jest zaś model prawotwórstwa deliberatywnego (negocjacyjnego), gdzie norma prawna traktowana jest jako efekt zderzenia różnych racji i kontrracji ${ }^{75}$, prezentowanych przez możliwie rozległą rzeszę podmiotów, zaangażowanych $\mathrm{w}$ mechanizm legislacyjny na różnych jego etapach, z różnymi możliwościami działania i oddziaływania ${ }^{76}$. Uspołecznienie procesu tworzenia prawa jest dzisiaj faktem obiektywnym, któremu nie można zaprzeczyć ani któremu nie można postawić skutecznej tamy, choć pośród adherentów autokratycznego modelu prawotwórstwa nie

${ }^{73}$ Szerzej na ten temat zob. K. Działocha, J. Trzciński, K. Wójtowicz, Studia nad udziatem grup interesów w procesie tworzenia prawa, Wrocław 1978, passim.

${ }^{74}$ Por. R. Piotrowski, Spór o model....., s. 34 i nast.

75 Szerzej na ten temat zob. A. Krzewińska, Deliberacja. Idea, metodologia, praktyka, Łódź 2016, s. 17 i nast.

${ }^{76}$ Jest tak gdyż każdy prawodawca internalizuje preferencje określonych grup społecznych i staje się jednocześnie ich reprezentantem, a tworząc prawo stara się łączyć, często sprzeczne i kolidujące ze sobą wartości. Por. J. Wróblewski, Polityka tworzenia prawa a hierarchia wartości, „Państwo i Prawo” 1983, nr 9, s. 27-29. 
cieszy się ono poważaniem ${ }^{77}$. Prawda jest taka, że owo uspołecznienie, choć rzeczywiście niesie ze sobą wartości budowania społeczeństwa obywatelskiego (którego przecenić się nie da), zwiera też w sobie niesłychanie wiele zjawisk niebezpiecznych i groźnych. Po pierwsze, co jest rzeczą najbardziej oczywista, ale też i najprostszą jeśli idzie o rozwiązanie proceduralne, które zreorganizuje model procesu ustawodawczego stosownie do wymagań uspołecznienia, komplikuje ono proces ustawodawczy $^{78}$. Wspomniana komplikacja ma wymiar podmiotowy (włącza się przecież coraz to nowe podmioty $\mathrm{w}$ mechanizm prawotwórstwa $\left.{ }^{79}\right)$; ma też wymiar temporalny (siłą rzeczy wydłuża to czas potrzebny na przyjęcie prawa, w tym ustawy); ma w końcu wymiar proceduralny (gdyż wymaga stworzenia odpowiednich procedur, przy użyciu których owo uspołecznienie będzie się realizować). Po drugie, co jest już sprawą dużo poważniejsza, uspołecznienie procesu legislacyjnego stwarza poważne ryzyko otwarcia dyskursu prawotwórczego na argumenty mało merytoryczne, bardziej polityczne czy światopoglądowe, a niekiedy wręcz populistyczne. Dlatego wskazuje się, nie bez racji, że uspołecznienie procesu ustawodawczego per se obniża stopień jego profesjonalizmu, a to dlatego, że prowadzi do multiplikacji, a w konsekwencji do egzageracji „informacji wartościującej”. Ta jak powiedziono wcześniej, jest co prawda niezbędna $\mathrm{w}$ racjonalnie zorganizowanym procesie dochodzenia ustawy do skutku. ale nie może nigdy uzyskać statusu informacji dominującej, a tym bardziej rozstrzygającej. To z kolei dowodzi tego, że wiele wartości i stanów rzecz jakie winno się kojarzyć w procesie ustawodawczym jest względem siebie kolizyjnych, a nawet wzajemnie się wykluczających. Trudno bowiem z jednej strony zrealizować nakaz profesjonalizacji prac ustawodawczych, z drugiej zaś ich otwarcia na społecznych uczestników mechanizmu prawotwórczego. Dlatego też prawidłowo zorganizowany proces legislacyjny winien tak korelować poszczególne wartości składające się na konkretny model prawotwórstwa, aby maksymalizować ich wszystkie możliwe awantaże, a zarazem minimalizować mankamenty

${ }_{77}$ H. Groszyk, A. Korybski, Instytucje prawne uspołecznienia procesów prawotwórczych, [w:] H. Rot (red.), Państwo, Prawo, Społeczeństwo. Zbór studiów, Wrocław 1992, s, 57 i nast.

78 Por. H. Rot, Uwarunkowania i wartości..., s. 123.

${ }^{79}$ Które to podmioty należy rozumieć szeroko, obejmując tym pojęciem również adresatów procesu legislacyjnego, jego użytkowników, a zwłaszcza jego beneficjentów. P. Chmielnicki, Podmioty objęte procesem normotwórczym, [w:] P. Chmielnicki (red.), Pochodzenie, tworzenie i efektywność prawa, Warszawa 2014, s. 135 i nast. 
i ich skutki uboczne. Po trzecie, niekontrolowane formy uspołecznienia prac ustawodawczych mogą generować zjawiska negatywne, a wręcz patologiczne, do których należy zaliczyć m.in. korupcję parlamentarną czy lobbing, szczególnie jeśli nie podlegają one jasnym i czytelnym mechanizmom instytucjonalizacji ${ }^{80}$. Po czwarte wreszcie, uspołecznienie procesu ustawodawczego, zwłaszcza kiedy przybiera zbyt duże rozmiary, może popaść w konflikt $\mathrm{z}$ konstytucyjnie założonymi zasadami i regułami legislacji. Przejawem tego jest (może być) podważenie podstawowej formy sprawowania władzy przez suwerena, jaką jest tzw. demokracja pośrednia (przedstawicielska). Ta pozostaje wszakże niewątpliwie zasadniczym mechanizmem sprawowania władzy przez naród (por. art. 4 ust. 2 Konstytucji). Demokracja bezpośrednia i będące jej konsekwencją uspołecznienie procesu tworzenia ustawy, może w efekcie podważyć pierwszorzędne znaczenie demokracji przedstawicielskiej (czego doskonale dowodzą te wszystkie przykłady, kiedy ludowe inicjatywy ustawodawcze próbuje się traktować jako ważniejsze wobec inicjatyw pozostałych podmiotów korzystających z prawa początkowania ustawodawstwa i kiedy formułuje się wręcz postulaty jedynie aprobującego sposobu odniesienia się do nich przez Sejm). Tymczasem konstytucyjna precedencja różnych form demokracji jest jasna i nie budzi wątpliwości. Na pierwszym miejscu pozostaje zawsze demokracja pośrednia (realizowana za sprawą wybieralnych organów tj. Sejmu i Senatu), na drugim zaś miejscu i to $\mathrm{w}$ charakterze formy $\mathrm{z}$ definicji komplementarnej jest postawiona demokracja bezpośrednia (realizowana nie tylko za sprawą referendum, obywatelskiej inicjatywy ustawodawczej ale też uspołeczniania procesu legislacyjnego). Pamiętać też trzeba, że nadmierne otwarcie procesu ustawodawczego na różnych społecznych jego uczestników może zachwiać tymi zasadami tego procesu, które ustalił już dawno Trybunał Konstytucyjny, a które dzisiaj wyznaczają standard prawidłowej (przyzwoitej) legislacji. Grozi przy tym przede wszystkim nadmierną polityzacją prawa rozumianą w tym przypadku jako preferencja dla argumentu politycznego, przedkładanego ponad wszystkie inne, zarówno racjonalne, jak i mniej racjonalne argumenty.

${ }^{80}$ Por. W.J. Wołpiuk, Lobbing a demokratyczne formy wptywu na stanowienie prawa, [w:] J. Wawrzyniak (red.), Tryb ustawodawczy..., s. 235 i nast. 
Biorąc powyższe pod uwagę, trzeba stwierdzić, że uspołecznienie procesu ustawodawczego jest dzisiaj koniecznością ${ }^{81}$, ale powinno być dokonywane ostrożnie i racjonalnie, żeby pozostawało $\mathrm{w}$ zgodzie $\mathrm{z}$ całym zestawem norm, zasad i wartości składających się na mechanizm dochodzenia ustawy do skutku. Próbując sformułować uwagi de lege ferenda wydaje się, że pożądane (oczekiwane) zmiany powinny objąć przynajmniej trzy akty normatywne, tj. ustawę z 24 czerwca 1999 roku o wykonywaniu inicjatywy ustawodawczej przez obywateli ${ }^{82}$; ustawę z 14 marca 2003 roku o referendum ogólnokrajowym ${ }^{83}$ i w końcu Regulamin Sejmu.

W pierwszym rzędzie warte rozważenia są zmiany ustawy o wykonywaniu inicjatywy ustawodawczej przez obywateli (detalizującej art. 118 ust. 2 Konstytucji). Zmianie powinien ulec przede wszystkim przepis art. 4 ust. 1 Konstytucji nakładający na projekt obywatelski wymóg złożenia projektu ustawy wraz z jego uzasadnieniem, stosownie do wymogów określonych w Regulaminie Sejmu. Godzi się przypomnieć, że w ten sposób akt powszechnie obowiązujący, jakim jest ustawa, odsyła do aktu "tylko" wewnętrznego, który w żaden sposób nie wiąże obywateli. Oczywiście nikt nie postuluje tutaj uwolnienia projektu obywatelskiego spod rygorów formalnych, których istnienie sprzyja realizacji zasady prakseologii i profesjonalizmu prac sejmowych. Powinno się jednak w tym przypadku przenieść wymogi, których spełniania oczekuje się od projektu zainicjowanego przez obywateli, do ustawy o wykonywaniu inicjatywy ustawodawczej przez obywateli, tym bardziej, że przepis art. 34 Regulaminu Sejmu różnicuje - jak wiadomo - określone tam wymagania w zależności od rodzaju (charakteru) podmiotu wykonującego inicjatywę. Przepisem, który powinien się również znaleźć w ewentualnie znowelizowanej ustawie z 24 czerwca 1999 r. o wykonywaniu inicjatywy ustawodawczej przez obywateli jest ustanowenie okresu karencji na wnoszenie projektów ustaw dotyczących tej samej materii. W obecnym stanie prawnym materialnie identyczne projekty ustaw, wnoszone w trybie art. 118 ust. 2 Konstytucji, mogą być wszak wnoszone permanentnie.

${ }^{81}$ Por. W. Gromaski, J. Repel, Niektóre kierunki i formy uspołecznienia procesu tworzenia prawa w krajach Europy Środkowo-Wschodniej, [w:] K. Działowcha (red.), Problemy tworzenia prawa..., s. 67 i nast.

${ }^{82}$ Ustawa z dnia 24 czerwca 1999 r. o wykonywaniu inicjatywy ustawodawczej przez obywateli, Dz. U. Nr 62, poz. 688 z późn. zm.

${ }^{83}$ Ustawa z 14 marca 2003 r. o referendum ogólnokrajowym, tekst jednolity Dz. U. z 2015 r., poz. 318 . 
W praktyce jest to sposobność, również i dla partii politycznych, do prowadzenia swoistej kampanii reklamowej, która częstokroć jest ważniejsza nawet aniżeli sam projekt ustawy. Trzeba zresztą zaznaczyć, że taki „kampanijny” charakter ludowej inicjatywy ustawodawczej podpowiada wykładnia historyczna instytucji umocowanej w art. 118 ust. 2 Konstytucji. Pokazuje ona niedwuznacznie, że w bardzo dużym stopniu była ona pomyślana jako alternatywa dla wnoszenia inicjatyw ustawodawczych przez partie polityczne, które znalazły się poza parlamentem (a w praktyce, jak wiadomo, korzystają z niej również ugrupowania parlamentarne). Dlatego nie chcąc w żadnej mierze nadmiernie krępować obywateli w wykonywaniu ich konstytucyjnych uprawnień, powinno się jednak zracjonalizować model ludowej inicjatywy ustawodawczej i wyraźnie zastrzec, że projekty materialnie, identyczne mogą być wnoszone np. po upływie dwunastu miesięcy od poprzedniego zaprezentowania Sejmowi danego projektu (jest to ważne zwłaszcza w momencie, kiedy Sejm nie uchwala ostatecznie ustawy, bowiem wówczas permanentne wnoszenie projektów $\mathrm{w}$ tych samych sprawach niepotrzebnie tylko angażuje izbę, a często ma sens jedynie polityczny, a nie merytoryczny). Inna, w praktyce jeszcze poważniejszą sprawą jest precyzyjne określenie uprawnień reprezentanta komitetu inicjatywy ustawodawczej. Tutaj jednak, bez stosownej zmiany Konstytucji nie można niczego uczynić. Przypomnieć więc się godzi, że Konstytucja w art. 119 ust. 4 pozwala wnioskodawcy na wycofanie zgłoszonego przez siebie projektu ustawy najpóźniej do zakończenia drugiego czytania. Z kolei art. 119 ust. 2 Konstytucji daje wnioskodawcy prawo wnoszenia poprawek do zgłoszonego przez siebie projektu. Jednocześnie art. 118 ust. 2 Konstytucji nie czyni żadnego wyłączenia stosowania art. 119 ust. 2 i 4 Konstytucji. W rezultacie ustawa z dnia 24 czerwca 1999 r. o wykonywaniu inicjatywy ustawodawczej przez obywateli uprawnienia wnioskodawcy ceduje na pełnomocnika komitetu inicjatywy ustawodawczej (o którym mówi art. 5 ust. 3 tej ustawy). Pojawia się jednak w tym miejscu uzasadniona wątpliwość czy z wszystkich uprawnień „wnioskodawcy" może i powinien korzystać „jedynie” pełnomocnik wnioskodawcy. Wydaje się, że projekt obywatelski, jako projekt firmowany nie tylko przez pełnomocnika komitetu inicjatywy ustawodawczej, ale przez grupe co najmniej 100 tyś. obywateli, powinien - na zasadzie wyjątku - nie podlegać „zwykłym” procedurom sejmowym, ergo nie powinny mieć do niego zastosowania przepisy art. 119 ust. 2 i ust. 4 Konstytucji (tym bardziej, że językowo patrząc na problem, uprawnienia w wnioskodawcy z art. 119 
ust. 2 i 4 Konstytucji nie mogą być tożsame z uprawnieniami „pełnomocnika wnioskodawcy").

Ustawa, która mogłaby również podlegać nowelizacji, przeprowadzonej pod ogólnym hasłem uspołeczniania procesu ustawodawczego, jest ustawa z dnia 14 marca 2003 r. o referendum ogólnokrajowym. Prima facie ustawa ta nie ma związku z procesem legislacyjnym. W praktyce jednak referendum ogólnokrajowe, szczególnie w sprawach o szczególnym znaczeniu dla państwa (art. 125 Konstytucji) ma postać referendum ustawodawczego, gdyż sprawy takie są regulowane na poziomie ustawy. Określenie reżimu proceduralnego postępowania z takim referendum, nolens volens, dotyczy więc procesu legislacyjnego. Tutaj elementem, który wymaga korekty jest postępowanie Sejmu w sprawie zarządzenia referendum w sprawach o szczególnym znaczeniu dla państwa. Art. 63 ust. 1 ustawy z 14 marca 2003 r. o referendum ogólnokrajowym mówi bowiem wyraźnie, że „Sejm może postanowić o poddaniu określonej sprawy pod referendum z inicjatywy obywateli, którzy dla swojego wniosku uzyskają poparcie co najmniej 500000 osób mających prawo udziału w referendum". Istotą regulacji jest więc, stosownie do brzmienia art. 125 Konstytucji, pozostawienie w wyłącznej gestii Sejmu podjęcia decyzji o zarządzeniu referendum. Wniosek obywateli $\mathrm{w}$ żadnym razie nie wiąże bowiem Sejmu, który dysponuje pełną swobodą $\mathrm{w}$ zakresie wyrażenia bądź niewyrażenia zgody na jego przeprowadzenie. Trzeba przyznać, że obecna regulacja jest racjonalna. Referendum jest bowiem, z jednej strony super-demokratyczną formą działania samego suwerena, czyli narodu. Jest jednak także, narzędziem, które może być (i w praktyce jest) używane i nadużywane z pobudek politycznych i populistycznych. W związku z powyższym wprowadzenie rozwiązania stwarzającego Sejmowi oblig zarządzenia referendum na wniosek obywateli byłoby nadmiernie niebezpieczne, gdyż w praktyce mogłoby skutkować ciągłym odwoływaniem się do referendum $\mathrm{w}$ imię realizacji partykularnych, ad hoc zgłaszanych pomysłów i propozycji, często o wyraźnie partykularnym czy sekcjonalnym zabarwieniu. $Z$ drugiej strony równie krytycznie należy ocenić dotychczasową praktykę, w której Sejm w sposób stały odmawia zarządzenia referendum na wniosek złożony przez grupę co najmniej pół miliona obywateli, nawet jeśli grupa ta znacznie przewyższa minimum określone w ustawie. Dlatego wydaje się, że rozwiązaniem optymalnym przy pozostawieniu co do zasady obecnych rozwiązań ustawowych w tej sprawie, jest wprowadzenie dodatkowego przepisu, który nakładał- 
by na Sejm obowiązek zarządzenia referendum, o ile liczba podpisów pod wnioskiem przekroczyłaby np. trzy- bądź czterokrotność minimum przewidzianego w art. 63 ust. 1 ustawy z 14 marca 2003 r. o referendum ogólnokrajowym. Wydaje się, że tego rodzaju rozwiązanie zapewniałoby minimum racjonalności i sprawności działania całej procedury, a jednocześnie odpowiadałoby art. 4 Konstytucji, w którym przecież demokracja bezpośrednia została potraktowana jako komplementarna, ale nie marginalna forma demokracji.

Wreszcie pewnych korekt wymagałyby przepisy Regulaminu Sejmu. Co prawdo zrobiono już sporo w celu uspołecznienia procesu ustawodawczego ale nie zawsze wprowadzone rozwiązania okazały się być zadawalające. Wydaje się przy tym, że oczekiwań nie spełnia przede wszystkim instytucja wysłuchania publicznego (art. 70a-70i Regulaminu Sejmu). Jej zasadniczym mankamentem, jest procedura dotycząca wnioskowania w przedmiocie podjęcia uchwały komisji sejmowej w sprawie przeprowadzenia wysłuchania publicznego. $\mathrm{W}$ istniejącym stanie prawnym wniosek taki może zgłosić wyłącznie poseł (art. 70a ust. 3 Regulaminu Sejmu). Z kolei prawo wzięcia udziału w wysłuchaniu publicznym mają podmioty wskazane w art. 70b ust. 1 i ust. 2 Regulaminu Sejmu. Wydaje się, że pożądanym rozwiązaniem byłoby tutaj poszerzenie kręgu wnioskodawców przeprowadzenia wysłuchania publicznego, jak i inne określenie podmiotów, które mogą wziąć udział w wysłuchaniu (bez oczywiście naruszania obecnej zasady, że uchwałę w sprawie przeprowadzenia wysłuchania podejmuje komisja). Po pierwsze wniosek w sprawie przeprowadzenia wysłuchania publicznego powinny móc zgłosić, poza posłami, organizacje społeczne, fundacje, stowarzyszenia oraz organizacje pracodawców i pracobiorców o uregulowanej sytuacji prawnej. Z logicznego punku widzenia to one bowiem, a nie posłowie, są najbardziej zainteresowane wysłuchaniem publicznym. Po drugie, można by było rozważyć dopuszczenie zgłaszania wniosków przez ad hoc zorganizowane grupy obywateli, co usprawiedliwione by było wnioskowaniem a maiori ad minus w stosunku do obywatelskiej inicjatywy ustawodawczej. Mówiąc krótko, skoro obywatele mogą więcej ( $\mathrm{zn}$. złożyć w Sejmie projekt ustawy) to powinni też móc mniej, co w tym przypadku oznacza złożenie wniosku o przeprowadzenie wysłuchania publicznego w odniesieniu do procedowanego w Sejmie projektu ustawy. Oczywiście kwestią do ustalenia pozostałoby wówczas określenie ilości osób (podpisów) niezbędnych do skutecznego złożenia wniosku w tej sprawie. Z kolei określenie uczestników wysłu- 
chania publicznego powinno nastąpić w sposób zbliżony do tego, w jaki to uczynił Regulamin Senatu. Prawo wzięcia udziału w wysłuchaniu publicznym ma tutaj każdy, kto zgłosił komisjom taką wolę co najmniej na 7 dni przed dniem wysłuchania publicznego, $\mathrm{w}$ formie pisemnej wskazując: 1) imię (imiona) i nazwisko oraz miejsce zamieszkania i adres - w odniesieniu do osób fizycznych, 2) nazwę, siedzibę i adres, a także imię (imiona) i nazwisko oraz miejsce zamieszkania i adres osoby reprezentującej na wysłuchaniu publicznym - w odniesieniu do osób prawnych i jednostek organizacyjnych niemających osobowości prawnej, 3) interes, który w odniesieniu do danej regulacji zamierza chronić lub rozwiązanie prawne, o którego uwzględnienie będzie zabiegać.

Wreszcie, czego cięgle nie ma w Polsce, a co występuje w niektórych państwach europejskich (np. w Wielkiej Brytanii) uspołecznienie procesu ustawodawczego powinno następować w formach właściwych dla tzw. e-rządzenia ${ }^{84}$. Wydaje się że rozwiązaniem minimalnym jest dopuszczenie możliwości zgłaszania przez obywateli i ich organizacje uwag do zainicjowanych projektów ustaw. Można tutaj pomyśleć o wprowadzeniu rozwiązania zakładającego, że od momentu podania projektu do publicznej wiadomości na stronach internetowych Sejmu do czasu zakończenia pierwszego czytania każda osoba fizyczna i prawna (oczywiście nie anonimowa) może zgłosić do ogłoszonego projektu swoje uwagi, postulaty i propozycje poprawek. Komisja sejmowa, zajmująca się szczegółowym rozpatrzeniem projektu musiałaby wówczas w swoim sprawozdaniu zamieścić informację o tym czy takie uwagi obywatelskie wpłynęły, jeśli tak to jaki miały charakter i co w odniesieniu do nich rekomenduje komisja Sejmowi. Wydaje się, że tego rodzaju rozwiązanie byłoby szczególnie pożądane. Ze społecznego i politycznego punktu widzenia dałoby ono obywatelom autentyczne poczucie nie tylko bycia poinformowanymi, ale bycia realnym uczestnikami sejmowego procesu ustawodawczego co dla budowania społeczeństwa obywatelskiego, rzeczywiście partycypującego w sprawach publicznych, ma wręcz kapitalne znaczenie. Z drugiej strony nie naraziłoby w niczym praw Sejmu, ani nie spowolniałoby jego prac. Nie uszczuplałby też w niczym Sejmu jako konstytucyjnego nośnika władzy ustawodawczej. Z kolei z marketingowego punktu widzenia lokowałoby Sejm w popularnej i atrakcyjnej dzisiaj formule rządzenia elektronicznego.

${ }^{84}$ Szerzej na ten temat zob. J. Rzucidło, Rząd elektroniczny. Aspekty konstytucyjnoprawne, Warszawa 2015, s. 59 i nast. 


\section{Kontrola procesu ustawodawczego}

Rozważając ewentualne zmiany, których celem miałoby być doskonalenie procesu ustawodawczego, nie można pominąć zagadnienia kontroli tego procesu. Stąd czwartym hasłem, wskazującym grupę problemów do rozważenia, jest hasło "proces ustawodawczy bardziej kontrolowany". Mówiąc o kontroli procesu dochodzenia ustawy do skutku powinno się mieć na myśli dwa aspekty tej kontroli. Pierwszym jest kontrola prawna, której istotą jest przestrzeganie zarówno pozytywnego, jak i negatywnego obowiązku ustawodawcy zwykłego. W tym pierwszym przypadku chodzi o to, że parlament (Sejm i Senat) są zobowiązane do wydawania ustaw zgodnych z Konstytucją oraz, co należy szczególnie podkreślić, rozwijających Konstytucję i pozwalających na jej pełną aplikację w obrocie prawnym. W tym drugim przypadku, określanym mianem negatywnego obowiązku ustawodawcy zwykłego, chodzi z kolei o to, żeby parlament powstrzymał się od stanowienia prawa niezgodnego z Konstytucją. Nadmienić w tym miejscu trzeba, że realizacja obu wskazanych wyżej obowiązków ustawodawcy zwykłego w niczym nie uszczupla praw ani idei sądownictwa konstytucyjnego. W stosunku do tego ostatniego, zarówno pozytywny, jak i negatywny obowiązek Sejmu mają charakter uzupełniający. System kontroli konstytucyjności prawa jest bowiem systemem złożonym. System, który Trybunał Konstytucyjny wieńczy, a nie wypełnia w sposób całkowity. Powinnością Sejmu i odpowiednio Senatu jest więc dołożenie należytej staranności w wydawaniu ustawy. Powinność taka wynika nie tylko z ogólnych zasad prakseologii procesu prawotwórczego, ale również z konstytucyjnych zasad, których podmioty władzy ustawodawczej zobowiązane są bezwzględnie przestrzegać. Chodzi tutaj przede wszystkim o zasady: rzetelnego i sprawnego działania instytucji (preambuła); demokratycznego państwa prawnego (art. 2 Konstytucji); legalności (art. 7 Konstytucji) oraz prawidłowej bądź przyzwoitej legislacji ${ }^{85}$ (którą Trybunał Konstytucyjny odkodował z zasady państwa prawnego ${ }^{86}$.

Wydaje się, że regulaminowe warunki prowadzenia kontroli konstytucyjności i legalności ustawodawstwa przez Sejm i jego organy są uregu-

${ }^{85}$ Por. J. Zaleśny, Zasady prawidłowej legislacji, „Studia Politologiczne” 2009, vol. XIII, s. 11 i nast.

${ }^{86}$ Szerzej na ten temat zob. M. Ziółkowski, Standard legalności stanowienia ustawy w orzecznictwie konstytucyjnym, [w:] P. Radziewicz (red.), Kontrola legalności ustawy w Sejmie, Warszawa 2015, s. 239 i nast. 
lowane w sposób prawidłowy. Trudno jest mówić o tym, że któryś z organów Sejmu czy też któryś z etapów procesu legislacyjnego jest szczególnie odpowiedzialny za badanie konstytucyjności (legalności) tworzonego prawa $^{87}$. Wydaje się, że wszystkie momenty parlamentarnego postępowania ustawodawczego mają tutaj równie ważne znaczenie. Niemniej rola wyjątkowa przypada z pewnością Marszałkowi Sejmu i komisji ustawodawczej. Poza tym odpowiedniego działania, sprofilowanego na badania ustawy pod kątem jej zgodności z Konstytucją należy oczekiwać od Senatu, który przecież - już standardowo - spełnia rolę izby refleksji i rozwagi bądź - jak niektórzy mówią - izby zadumy ustawodawczej bądź powściągliwości ustawodawczej ${ }^{88}$.

Niemniej warto wskazać parę spraw, które są dzisiaj albo dyskusyjne i nie do końca racjonalne albo takie, których nie ma, a o których można by było pomyśleć. Sprawą ciągle wątpliwą (sygnalizowaną już przez doktrynę prawa konstytucyjnego) są procedury przewidziane w art. 34 ust. 8 Regulaminu Sejmu. O pewnych wątpliwościach w tej sprawie była już mowa wcześniej. Tutaj trzeba zwrócić uwagę na inne zagadnienia. Po pierwsze na to, że w brzmieniu art. 34 ust. 8 Regulaminu Sejmu nie ma w ogóle mowy o zgodności projektu z Konstytucja; po drugie, że jest tam z kolei mowa o zgodności z „podstawowymi zasadami techniki prawodawczej". W tym przypadku pojawia się problem, co konkretnie autor Regulaminu Sejmu miał na myśli. Czy miał on na myśli rozporządzenie Prezesa Rady Ministrów z 20 czerwca 2002 r. w sprawie „zasad techniki prawodawczej" ${ }^{89}$, czyli konkretny akt normatywny czy też raczej miał on na myśli ogólne wzorce, według których powinno się konstruować przepisy (popularnie także przecież zwane zasadami techniki prawodawczej). Po trzecie, nie do końca jasne jest określanie „sprzeczności z prawem”, którym posługuje się art. 34 ust. 8 Regulaminu Sejmu. Pojęcie sprzeczności z prawem można bowiem interpretować zarówno wąsko, jak i szeroko. Możne ono oznaczać jedynie sprzeczność z Konstytucją jak i sprzeczność (w szerszym tego słowa znaczeniu) z całym porządkiem prawnym, a tak-

${ }^{87}$ Cały ten proces podlega również kognicji Trybunału Konstytucyjnego. Szerzej na ten temat zob. A. Syryt, Kontrola trybu uchwalenia ustawy przed Trybunałem Konstytucyjnym, Warszawa 2014, passim.

${ }^{88}$ E. Popławska, Lepsze prawo - wyzwanie dla Senatu, [w:] J. Wawrzyniak (red.) Tryb ustawodawczy..., s. 113 i nast.

${ }^{89}$ Rozporządzenie Prezesa Rady Ministrów z 20 czerwca 2002 r. w sprawie „zasad techniki prawodawczej", tekst jednolity Dz. U. z 2016 r., poz. 283. 
że (jeszcze szerzej) sprzeczność z wartościami i zasadami określającymi tożsamość systemu prawnego w stopniu wykluczającym modyfikację zarówno tego systemu, jak i projektu. Przez sprzeczność z prawem można też rozumieć przypadki oczywistej sprzeczności projektów z prawem, które mają cechą nieusuwalnych i oczywistych wad. Wydaje się, że posługiwanie się przez autora Regulaminu Sejmu tak nieostrym, a przez to różnie interpretowanym pojęciem, jest niedopuszczalne, zwłaszcza, że w zależności od przyjętej interpretacji może ono skutkować dopuszczeniem bądź też niedopuszczeniem projektu do dalszych prac parlamentarnych. Korekty wymaga wreszcie, wskazana już wcześniej, możliwość alternatywnego działania Marszałka Sejmu. Wydaje się, że uchwała komisji ustawodawczej, podjęta szczególną większościa, bo większością trzech piątych głosów, powinna zamykać postępowanie w tej sprawie, a nie ciągle pozwalać Marszałkowi na nadanie biegu projektowi zdyskwalifikowanemu przez komisję.

Rzeczą wartą rozważenia jest też uczynienie z komisji ustawodawczej w jeszcze większym stopniu niż ma to miejsce obecnie organu sejmowego kontrolującego konstytucyjność tworzonego przez parlament prawa ${ }^{90}$. Wydaje się, że warte rozważenia byłoby np. dopuszczenie możliwości zgłoszenia przez każdy klub poselski (bądź kwantytatywnie wskazaną grupę posłów) wniosku do komisji ustawodawczej (np. do czasu zakończenia drugiego czytania) w sprawie zaopiniowania każdego rozpatrywanego przez Sejm projektu ustawy pod kątem jego zgodności z Konstytucją ${ }^{91}$ W ten sposób sejmowa komisja ustawodawcza stałaby się de facto swoistym pilotem kontroli konstytucyjności ustawy w Sejmie, a jednocześnie istotne narzędzie wpływu na przebieg postępowania ustawodawczego uzyskałyby opozycyjne kluby parlamentarne ${ }^{92}$.

90 Por. R. Piotrowski, Parlamentarna kontrola kostyczności aktów prawnych, [w:] E. Zwierzchowski (red.), Prawo i kontrola jego zgodności z konstytucja, Warszawa 1997, s. 108 i nast.

${ }^{91}$ Co odpowiadało by w możliwie pełny sposób postulatowi rzetelności procesu ustawodawczego i czyniło by samych posłów (praz kluby i koła poselskie) w jeszcze większym stopniu odpowiedzialnymi za jakość stanowionego w państwie prawa i jego zgodność z konstatacją. Co więcej, chroniłoby to w większym stopniu prawa Sejmu, który w oczywistych przypadkach sam powinien nie dopuszczać do przyjmowania ustaw wadliwych, które później i ta zdyskredytuje Trybunał Konstytucyjny.

${ }_{92}$ Należy bowiem pamiętać, że ustanowienie organów pozaparlamentarnej kontroli konstytucyjności prawa nie zdejmuje bynajmniej obowiązku takiej kontroli po stronie parlamentu. Co więcej, zauważa się, ze w toku realizowanej przez parlament funkcji ustawodawczej musi on przestrzegać dwóch obowiązków, tj. tzn. pozytywnego obowiązku ustawodawcy zwykłego, który zawiera się w konieczności wydawania wszystkich niezbęd- 
Dochodzimy tutaj do drugiego wymiaru (aspektu) kontroli procesu ustawodawczego, jakim jest kontrola polityczna. Mówiąc w największym skrócie, chodzi o zagwarantowanie minimalnego i przyzwoitego statusu opozycji parlamentarnej. Godzi się wskazać, że w obecnych przepisach regulaminowych statusu takiego de iure nie ma. Owszem są poszczególne uprawnienia, przysługujące np. grupie 15 posłów ${ }^{93}$, a więc faktycznie również i grupom opozycyjnym, ale ex officio opozycja nie jest ujęta w ramy przepisów regulaminowych, bo i sam termin „opozycja” ani razu nie pojawia się w Regulaminie Sejmu. Wydaje się, że czas najwyższy aby ten stan rzeczy zmienić. Dzisiaj jednym z kryteriów demokratyczności rozwiązań ustrojowych jest wszak instytucjonalizacja opozycji parlamentarnej, której sprawne działanie jest ważnym elementem demokratycznego państwa prawnego. Dlatego należy rozważyć wprowadzenie do Regulaminu Sejmu postanowień, które wprost odnosić się będą do opozycji, i które opozycji zapewnią swobodę działania i krytyki rządu (bo to przecież jest kwintesencja funkcjonowania opozycji $)^{94}$.

Sprawą najważniejszą jest rozstrzygniecie kwestii komu przyznać regulaminowy status opozycji (ewentualnie Oficjalnej Opozycji ${ }^{95}$ ). Można

nych usta, które uczynią konstytucję aktem w pełni stosowalnym oraz tzn. negatywnego obowiązku ustawodawcy zwykłego, który formułuje pod adresem parlamentu wyraźny zakaz wydawania ustaw niezgodnych z Konstytucją. W efekcie, obowiązkiem parlamentu jest stworzenie procedur, które mógłby mieć zastosowanie na okoliczność kontrolowania zgodności prawa z Konstytucją już na etapie procesu ustawodawczego przebiegającego w parlamencie. Szerzej na ten temat zob. J. Jaskiernia, Zasady demokratycznego państwa prawnego w sejmowym postepowaniu ustawodawczym, Warszawa 1999, s. 398 i nast.

${ }_{93}$ Co niekiedy postrzegane jest jako pośrednia forma zainstalowania praw opozycji parlamentarne, Por. S. Bożyk, Opozycja parlamentarna w Sejmie RP..., s. 86-87.

${ }_{94}$ Tego rodzaju postulaty, obejmujące zresztą nie tylko poziom regulaminu Sejmu ale również i Konstytucji RP są w doktrynie prawa konstytucyjnego zgłaszane od dawna. Por np. K. Complak, Opozycja parlamentarna w obowiazującej i przyszłej Konstytucji RP, „Przegląd Sejmowy" 1995, nr 2, s. 27 i nast.

95 Można oczywiście również zagwarantować prawa opozycji bez równoczesnego wprowadzenia pojęcia „opozycji” do przepisów Regulaminu Sejmu. W takim jednak przypadku należałoby zagwarantować określone prawa dla mniejszości (grupy posłów), która mogłaby z konkretnie wskazanych uprawnień skorzystać. Niemniej takie rozwiązanie nie dawałoby gwarancji, że z praw mniejszościowych nie będą korzystać posłowie należący do koalicji bądź partii rządzącej. Tymczasem sednem instytucjonalizacji opozycji (w różnym wymiarze) jest to aby grupie bądź grupom mniejszościowym dać do ręki uprawnienia, zarezerwowane włącznie dla nich, a zatem takie, z których nie mogą korzystać posłowie popierający rząd. Dlatego - jak się zdaje - tak bardzo postulowane jest zawarcie w przepisach regulaminowych stosownych postanowień i zaadresowanie ich nie do jakiejkolwiek grupy posłów ale właśnie do opozycji. Tylko to zapewni bowiem narzędzia 
bowiem przyjąć, jak to ma miejsce tacite dzisiaj, że opozycją są wszystkie kluby poselskie, które nie wchodzą w skąd rządu bądź koalicji rządowej. Przyjęcie takiego założenia powoduje jednak najczęściej, czego ilustracją jest obecny Regulamin Sejmu, że opozycją są właściwie wszyscy inni, co nie wymaga odrębnej regulacji działania owej opozycji. Dlatego wydaje się, że potencjalna jurydyzacja opozycji w Regulaminie Sejmu ${ }^{96}$ powinna wyglądać w ten sposób, że status opozycji (Oficjalnej Opozycji) przyznaje się albo największemu klubowi poselskiemu, który nie tworzy aktualnie rządu ani koalicji rządowej albo - opcjonalnie - klubom, które w określonym czasie po zaprzysiężeniu nowego rządu (np. 7 dni) zgłoszą (np. Marszałkowi Sejmu) chęć pozostawania w opozycji. W tym drugim przypadku wymóg notyfikacji faktu pozostawania w opozycji jest wskazany, gdyż równie dobrze można sobie wyobrazić sytuację, w której klub poselski co prawda nie wchodzi w skład rządu (koalicji rządowej) ale zarazem nie jest wobec niego ustosunkowany opozycyjnie i przynajmniej okazjonalnie może popierać rząd. Poza tym można sobie wyobrazić sytuację (co potwierdza praktyka), że klub poselski choć oficjalnie nie wchodzi w skład koalicji rządowej, to jednak tworzy tzw. koalicję parlamentarna, a w rezultacie popiera $\mathrm{w}$ głosowaniach sejmowych stanowisko rządu. Z wyżej przedstawionych powodów najlepszą formą regulaminowego określenia kto tworzy opozycję jest albo: 1) przyznanie niejako z automatu statusu opozycji największemu klubowi, który pozostaje poza składem rządu (kolacji rządowej) albo 2) zawiadomienia w określonym terminie przez klub bądź kluby poleskie, że chce on (chcą one) pozostawać w stosunku do rządu w opozycji. Wydaje się przy tym, że zdecydowanie lepszym i prostszym rozwiązaniem jest pierwsza ze wskazanych sytuacji.

Przyznanie w Regulaminie Sejmu konkretnie wskazanemu klubowi (ewentualnie klubom) oficjalnego statusu opozycji powinno pociągnąć za sobą przyznanie praw opozycji, tak aby była ona realną instytucją prawa parlamentarnego. Pamiętać wszak trzeba, że opozycja nie jest czymś złym, czymś co niepotrzebnie przeszkadza rządowi i utrudnia wykonywanie mu jego zamierzeń politycznych, ale wręcz odwrotnie, opozycja

oddziaływania na pracę parlamentu ugrupowaniom, które aktualnie nie popierają polityki prowadzonej przez większość.

${ }_{96}$ Która to jurydyzacja (instytucjonalizacja) jest już w świecie pewnym uznanym standardem, do tego stopnia, że opozycję parlamentarna podnosi się wręcz do rangi instytucji konstytucyjnej. Szerzej na temat sposobów instytucjonalizacji opozycji zob. E. Zwierzchowski (red.), Opozycja parlamentarna, Warszawa 2000, passim. 
- w demokratycznie zorganizowanym państwie - spełnia ożywczą rolę, realizując trzy kluczowe funkcje ${ }^{97}$. Mianowice funkcję kontrolną (dokunując uważnego przeglądu działalności rządu i poszczególnych ministrów); funkcję deliberacyjną (ewokuje debatę publiczną) i wreszcie spełnia niezwykle istotną funkcję kształtowania alternatywy programowej (poprzez składanie własnych propozycji i krytykę programu rządowego). Wydaje się, że pożądane zmiany regulaminu sejmowego powinny być tak przeprowadzone, aby umożliwić opozycji w miarę sprawną i pełną realizację tych trzech, przedstawionych wyżej funkcji. Oczywiście w szerszym ujęciu, regulaminowa regulacja statusu opozycji parlamentarnej powinna być skorelowana z tymi postanowieniami Regulaminu Sejmu, które zapewnią pluralistyczny obraz składu Sejmu i jego organów. Stąd propozycje instytucjonalnego zakotwiczenia opozycji będą tutaj przedstawione razem z tymi możliwymi (preferowanymi) rozwiązaniami, które ów pluralizm politycznopartyjnego oblicza Sejmu mogłyby zagwarantować.

Do rozważenia można przedstawić tu m.in.: 1) wyraźne wprowadzenie do Regulaminu Sejmu normy, która gwarantuje reprezentację w Prezydium Sejmu wszystkim klubom poselskim (co oznacza przyznanie prawa posiadania wicemarszałka Sejmu każdemu klubowi); 2) idąc dalej tym tropem można w ogóle powiązać funkcję wicemarszałka Sejmu z klubem, co gwarantowałoby, że osoba wicemarszałka Sejmu, która porzuca klub parlamentarny z którym stanowisko wicemarszałka jest powiązane, traci to stanowisko (jak wiadomo wątpliwie przypadki innego ukształtowania praktyki w tym względzie znamy z doświadczenia, co wywoływało niejednolite oceny doktryny); 3) opcjonalnie, jeśli uchwałodawca nie zdecydowałby się na pierwsze ze wskazanych rozwiązań, należy bezwzględnie wprowadzić przepis, który prawo do wicemarszałka przyznaje np. klubom liczącym co najmniej dwukrotność minimalnego składu klubu (co znowu zabezpieczałoby przed naganną praktyka, kiedy to duże kuby poselskie nie miały swojego reprezentanta w Prezydium Sejmu); 4) należałoby wprowadzić przepis, który expressis verbis potwierdzi, że składy osobowe komisji sejmowych muszą w swoim składzie politycznym odzwierciedlać proporcję składu Sejmu; 5) instytucjonalizując opozycję powinno się również zagwarantować jej prawo do powoływania przewodniczących określonej liczby stałych komisji sejmowych (np. co najmniej

97 Szerzej na ten temat zob. Z. Machelski, Opozycja w systemie demokracji parlamentarnej. Wielka Brytania, Niemcy, Włochy, Warszawa 2001, s. 36 i nast. 
jednej czwartej komisji); 6) wydaje się, że sensownym rozwiązaniem byłoby, konsekwentnie do wcześniej zgłoszonego wniosku, zagwarantowanie opozycji przewodnictwa w kilku, z góry wskazanych komisji np. komisji etyki polskiej czy komisji regulaminowej i spraw poselskich, 7) powinno się również wprowadzić przepis, który wyeliminuje możliwość powoływania przewodniczącego i wiceprzewodniczącego stałej komisji z jednego klubu poselskiego; 8) opozycja parlamentarna (posiadająca taki status regulaminowy) powinna wreszcie otrzymać prawo do określania porządku dziennego jednego z posiedzeń Sejmu (np. co piątego posiedzenia). To rozwiązanie, znane z praktyki innych państw (np. Wielkiej Brytanii) jest bowiem jednym z najważniejszych uprawnień opozycji parlamentarnej, które z jednej strony pozwala jej skutecznie działać, z drugiej zaś nie wywołuje destabilizacji rządu ani prac rządowych. Wreszcie 9) Regulamin Sejmu powinien „odbudować” zdewastowaną instytucję interpelacji, tym bardziej, że ma ona swoje mocne, bo konstytucyjne zakotwiczenie (por. art. 115 Konstytucji - w żadnym razie nie naprawiła tego regulaminowa instytucja żądania informacji przyznana klubom i grupom liczącym co najmniej 15 posłów). Godzi się przypomnieć, że interpelacja jest tradycyjną instytucją prawa parlamentarnego, której sensem jest: a) zadanie pytania w sprawach o szczególnym znaczeniu; b) przez to zwrócenie uwagi opinii publicznej na sprawę będącą przedmiotem interpelacji; c) i w końcu wywołanie debaty plenarnej (co odpowiada funkcji deliberacyjnej jaką spełnia opozycja parlamentarna). Tymczasem w obecnym stanie prawnym sens interpelacji został zaprzepaszczony, zwłaszcza że odpowiedź na nią nie może być powodem wszczęcia debaty parlamentarnej (a o to przecież zawsze chodzi opozycji, bo to naświetla potknięcia i słabe punkty rządu, a zarazem pokazuje kontrolne nachylenie działania opozycji ${ }^{98}$. Wydaje się więc, że pożądanym stanem byłaby restytucja interpelacji w jej oryginalnym wydaniu ( $z n$. z możliwością przeprowadzania debaty sejmowej), ale jednocześnie z zastrzeżeniem, że prawo interpelowania członków Rady Ministrów miałby klub (kluby) mający status oficjalnej opozycji. W ten sposób z żądania informacji korzystałyby wszystkie pozostałe kluby i grupy minimum 15 posłów, podczas gdy interpelacja byłaby instrumentem pozostającym w rękach opozycji (co niewątpliwie podnosiłoby

98 Szerzej na ten temat zob. M. Kruk, Funkcja kontrolna Sejmu RP, Warszawa 2008, s. 63 i nast. Zob. także J. Zaleśny, Dynamika procedur interpelacyjnych. Doświadczenia okresu transformacji w wymiarze wertykalnym, [w:] M. Kruk, J. Wawrzyniak (red.), Transformacja ustrojowa w Polsce. 1989-2009, Warszawa 2011, s. 97 i nast. 
jej ustrojową rangę). Można w końcu pomyśleć o tym, że 10) wniosek do komisji ustawodawczej (proponowany wcześniej), który byłby formą kontroli legalności i konstytucyjności procesu legislacyjnego mogłaby złożyć wyłącznie opozycja. Dzięki temu prawo żądania od komisji ustawodawczej przygotowania opinii o zgodności procedowanego projektu z konstytucją pozostawałoby w dyspozycji nie wszystkich klubów poselskich, ale klubu (klubów) mających formalny status oficjalnej opozycji parlamentarnej. Taka ewentualność również podkreślałaby znaczenie opozycji i jej ustrojową rangę $e^{99}$.

\section{Efektywność procesu ustawodawczego}

Wszystkie przedstawione propozycje mają w sumie spełnić ostatni, w gruncie rzeczy najważniejszy postulat optymalizacji prac legislacyjnych jakim jest zwiększenie efektywności procesu ustawodawczego. Każda ze zgłoszonych propozycji, w swoim finalnym skutku ma przecież doprowadzić do zwiększenia skuteczności i jakości procesu dochodzenia ustawy do skutku. Wydaje się jednak, że mówiąc o procesie ustawodawczym bardziej efektywnym można jeszcze, wskazać (zaproponować) co najmniej dwa rozwiązania, które będą temu sprzyjały. Oba dotyczą przy tym relacji Sejmu z otoczeniem, jakim jest Rada Ministrów z jednej strony oraz Senat, $\mathrm{z}$ drugiej.

Jeśli idzie o Radę Ministrów, to nie ulega wątpliwości, że obok Sejmu stanowi ona zasadniczy podmiot prac ustawodawczych ${ }^{100}$. Raz jeszcze podkreślić wypada, że nie jest to żaden defekt systemu, ale efekt tego, że wpisany jest on w ramy parlamentaryzmu, a te wymagają współdziałania rządu i parlamentu w procesie prawotwórczym, szczególnie w przypadku tworzenia ustawy. Z tego punktu widzenia patrząc należy żałować, że liczne nowelizacje ustawy z 8 sierpnia 1996 r. o Radzie Ministrów ${ }^{101}$ nie zapewniły dostatecznej instytucjonalizacji właściwiej komórki Kancelarii

${ }^{99}$ Która to rola ciągle w polskim Sejmie jest niedoceniana, a w rzeczywistości stanowi oś napędową jego pracy. Por. M. Kruk, Parlament w dobie transformacji, [w:] M Kruk, J. Wawrzyniak (red.), Transformacja ustrojowa..., s. 77, 78.

100 M. Mistygacz, Rząd w procesie ustawodawczym w Polsce, Warszawa 2012, s. 111 i nast.

101 Ustawa z 8 sierpnia 1996 r. o Radzie Ministrów, tekst jednolity, Dz. U. z 2012 r., poz. 392. 
Prezesa Rady Ministrów zajmującej się kontaktami z Sejmem (Senatem) na etapie postępowania ustawodawczego. Zadania Rządowego Centrum Legislacji mimo wszystko są nico inne, a samo Centrum nie jest podmiotem, który monitoruje przebieg rządowych przedłożeń legislacyjnych na etapie ich parlamentarnego rozpatrywania (a dzisiaj z oczywistych powodów robi to w bardzo ograniczonym stopniu). Patrząc na doświadczenia innych państw wypada żałować, a zarazem wnioskować o powoływanie w składzie Rady Ministrów (najlepiej w randzie podsekretarza stanu) osoby odpowiedzialnej za kontakty z Sejmem (Senatem), której zasadniczym zadaniem byłoby pilotowanie rządowych projektów ustaw w parlamencie oraz gwarantowanie uwzględniania przez parlament stanowiska rzą$\mathrm{du}$ w tej sprawie (bo to jest sensem obecności tego podmiotu ${ }^{102}$ ). Odpowiednia komórka, w postaci departamentu czy biura np. ds. kontaktów z parlamentem jest więc najzwyklejszym wymogiem prakseologii procesu legislacyjnego ${ }^{103}$.

Innym problemem, $\mathrm{w}$ przypadku parlamentu dwuizbowego niejako naturalnym, jest określenie zasad współdziałania obu izb (Sejmu i Senatu), szczególnie w tych przypadkach, kiedy izby różnią się między sobą co do meritum procedowanej ustawy. Jak wiadomo polska Konstytucja przewiduje, typowy zresztą dla większości państw europejskich, model dwuizbowości asymetrycznej (nierównorzędnej), w której izba pierwsza (Sejm) odgrywa rolę dominująca, zaś izba druga (Senat) jest izbą korekcyjną ${ }^{104}$. Brak równorzędności Sejmu i Senatu, w zakresie trybu ustawodawczego potwierdza najlepiej art. 121 Konstytucji , przyznający Sejmowi „prawo ostatniego słowa” jeśli idzie o treść i kształt uchwalanej ustawy. Jednocześnie Konstytucja ustanawia expressis verbis dwa wyjątki od tego normalnego stanu asymetryczności izb. Pierwszym jest tryb zmiany samej Konstytucji (art. 235 Konstytucji), drugim natomiast parlamentarny sposób wyrażenia zgody na ratyfikację umowy międzynarodowej przekazującej organizacji bądź organowi międzynarodowemu kompetencje

102 Por. R. Chruściak, Przygotowywanie rzadowych projektów ustaw, „Przegląd Legislacyjny" 2004, nr 2, s. 70 i nast.

${ }^{103}$ Szczególnie w warunkach systemu parlamentarnego (parlamentarno-gabinetowego), w którym wymaga się kooperacji legislatywy i egzekutywy, głównie w zakresie legislacji, która w ostateczności zawsze postrzegana jest jako wynik współdziałania rządu i parlamentu.

104 Szerzej na ten temat zob. m.in.: M. Dobrowolski, Zasada dwuizbowości parlamentu w polskim prawie konstytucyjnym, Warszawa 2003, s. 135 i nast.; T. Litwin, Funkcje Sejmu i Senatu a wspótczesny polski model dwuizbowości, Warszawa 2016, s. 42 i nast. 
władz państwa w niektórych sprawach (art. 90 Konstytucji). Co ważne, w żadnym przepisie Konstytucji, dotyczącym zarówno trybu „zwykłego”, gdzie izby są asymetryczne, jak i dwóch trybów „wyjątkowych”, gdzie rola Senatu jest zrównana ( $w$ jakimś senesie) z rolą Sejmu nie przewidziano żadnych mechanizmów koncyliacyjnych między izbami. Polski model dwuizbowości cechuje więc zdecydowana asymetryczność (z dwoma wyjątkami) oraz swoista "akoncyliacyjność” (czyli absencja procedur, które doprowadzić by miały do uzgadniania stanowisk obu izb w razie zaistnienia różnicy zdań). To rozwiązanie, choć jak najbardziej odpuszczane, może jednak godzić w racjonalny proces tworzenia prawa, zwłaszcza jeśli uzupełnimy go popularną dzisiaj koncepcją „negocjacyjnego prawotwórstwa", zakładającego, że finalny produkt procesu ustawodawczego, tj. ustawa jest wynikiem permanentnych uzgodnień i negocjacji prowadzonych między różnymi podmiotami ${ }^{105}$.

Pojawia się więc pytanie, czy w obecnych granicach konstytucyjnych jest możliwe wprowadzenie pewnych procedur koncyliacyjnych, $\mathrm{np}$. w postaci komisji wspólnej Sejmu i Senatu, funkcjonującej bądź to w sposób stały, bądź też angażowanej ad hoc, w przypadku zaistnienia różnicy zdań. Jak wiadomo z ograniczoną praktyką $\mathrm{w}$ tym względzie mieliśmy do czynienia na początku lat 90-tych ${ }^{106}$. Później jednak praktyka poszła w innym kierunku, tzn. braku mechanizmów koncyliacyjnych. Niemniej zdawać sobie trzeba sprawę z tego, że zwłaszcza po roku 1997 mechanizmy tego rodzaju były niepotrzebne i w jakimś sensie zastępowane polityczną zbieżnością Sejmu i Senatu, która per se minimalizowała odmienności stanowisk obu izb ${ }^{107}$. Argumentem przeciwko istnieniu wspólnej, poselsko-senatorskiej komisji był również ogólny model nierównorzędności izb zawarty w Konstytucji, a także brak wyraźnego dopuszczenia takiej możliwości przez Konstytucję. Dzisiaj kwestią sporną pozostaje czy

105 E. Kustra, Wtadczy i negocjacyjny typ tworzenia prawa, „Ruch Prawniczy, Ekonomiczny i Socjologiczny" 1994, nr 4, s. 24.

106 Por. P. Sarnecki, Senat RP i jego relacje z Sejmem (lata 1989-1993), Warszawa 1995 s. 63 i nast.

107 Zbieżności tego rodzaju w praktyce bardzo często w ogóle eliminują potrzebę ustanawiania mechanizmów porozumiewawczych między izbami, niemniej poddają w wątpliwość zasadniczy sens utrzymywania dwuizbowości. Wskazuje się bowiem, że niejako naturalnym środowiskiem dwuizbowości jest różnica w polityczno-partyjnych składów obu izb, skąd nomen omen bierze się potrzeba konstruowania prawa wyborczego na innych zasadach w pierwszej i w drugiej izbie parlamentu. Jeśli zbieżność polityczna obu izb utrzymuje się w dłuższym okresie sama zasada dwuizbowości jest kwestionowana i często określana mianem dwuizbowości pozornej czy sztucznej. 
przy istniejącym de lege fundamentali lata stanie prawnym powołanie tego rodzaju komisji jest dopuszczalne. Wydaje się, że pomimo bardzo czytelnego określenia roli izb parlamentarnych w procesie ustawodawczym i tego, że co do zasady rola Senatu jest rolą wtórną, można ustanowić jakiś mechanizm porozumiewawczy. Z pewnością nie mogłaby to być (śladem np. Niemiec ${ }^{108}$ ) stała komisja złożona z członków obu izb (co wymagałoby stosownej podstawy konstytucyjnej). Do pomyślenia jest jednak wariant tworzenia komisji ad hoc (a więc jeśli pojawi się spór między izbami) albo powoływania, równieżad hoc, delegacji obu izb, bez przyznawania im równoczesnego statusu komisji (co byłoby najbardziej „bezpieczne”). Wreszcie nie ma przeszkód regulaminowych, a tym bardziej konstytucyjnych, odbywania wspólnych posiedzeń komisji sejmowych i senackich, które procedowały nad danym projektem (ustawą) ${ }^{109}$. Jeszcze inną formą dialogu między izbami mogłyby być (np. wprost dopuszczone przez regulaminy obu izb) wspólne posiedzenia Prezydium Sejmu i Senatu. Podkreślić bowiem trzeba, że konstytucyjna absencja pewnych rozwiązań absolutnie nie przeszkadza w ich ustanoweniu na niższych szczeblach procedury prawotwórczej czy nawet jedynie w praktyce, bez rejestrowania tego faktu w przepisach prawa. Zasadniczym motywem tworzenia procedur parlamentarnych powinna być bowiem zawsze ich efektywnośćc ${ }^{110}$.

Zaproponowane rozwiązania ${ }^{111}$, sprowadzające się do punktów: 1) proces ustawodawczy bardziej racjonalny; 2) proces ustawodawczy bardziej profesjonalny; 3) proces ustawodawczy bardziej uspołeczniony;

108 Szerzej na ten temat zob. A. Szmyt, Komisja mediacyjna w RFN, „Przegląd Sejmowy” 1993, nr 3, s. 42 i nast.

109 Praktyka taka pojawiała się zresztą sporadycznie na początku lat 90-tych XX wieku. Niemniej warto zaznaczyć, że część przedstawicieli doktryny stoi na stanowisku, że praktyka taka, bez wyraźnego zezwolenia w Konstytucji, jest niedopuszczalna (np. Sławomir Patyra), co jednak wydaje się być poglądem nazbyt ostrym. Można bowiem stanąć na stanowisku, że praktyka taka wychodzi naprzeciw zasadzie współdziałania władz, która ma być determinantą działań wszystkich pionów podzielnej władzy, co wyraźnie postuluje preambuła do Konstytucji RP.

110 A tej sprzyjają wszelkiego rodzaju procedury koncyliacyjne ustanawiane w parlamencie dwuizbowym, bez względu na ich podstawę i na to, czy są jedynie przejawem praktyki, czy też formalnymi instytucjami prawnymi. Szerzej na ten temat zob. J. Szymanek, Postępowanie mediacyjne w parlamencie dwuizbowym, „Przegląd Sejmowy” 2004, nr 5, s. 47 i nast.

111 Nie są to zresztą pierwsze propozycje, gdyż dyskusja nad optymalizacją kształtu procesu stanowienia prawa trwa w Polsce nieprzerwanie od wielu lat. Por. S. Wronkowska, Tworzenie prawa w Polsce: ocena i proponowane kierunki zmian, "Przegląd Legislacyjny" 2006, nr 1, s. 7 i nast. 
4) proces ustawodawczy bardziej kontrolowany i wreszcie 5) proces ustawodawczy bardziej efektywny, są tylko luźnymi propozycjami, które mają wyjść naprzeciw rozmaitym dysfunkcjom obecnego modelu legislacji. Każdy przyjęty ostatecznie sposób tworzenia prawa, a zwłaszcza ustawy, musi bowiem korelować ze sobą często sprzeczne wartości i stany rzeczy. Ustanowienie „hurra-demokratycznych" procedur może się bowiem okazać efektowane ale zupełnie nieefektywne. $Z$ kolei nawiązanie do wzorców autokratycznego modelu prawa, choć często niesamowicie skutecznego zwłaszcza jeśli idzie o poziom merytorycznej i aksjologicznej spójności prawa, dyskredytuje prawo i prawodawcę, pozbawiając go społeczno-politycznej legitymizacji. Racjonalny prawodawca musi więc kojarzyć ze sobą różne wartości i wybierać sprawdzoną metodę „złotego środka”, tzn. demokratyzować procedury ustawodawcze ale zarazem gwarantować ich skuteczność. Na koniec raz jeszcze przypomnieć wypada, że nawet najlepiej skrojone procedury, nawet najbardziej optymalne rozwiązania na nic się zdadzą jeśli nie ma odpowiedniej kultury tworzenia prawa i wykreowanych przez nią zwyczajów i obyczajów politycznych, które tworzyć będą „społeczny klimat” dobrego prawotwórstwa.

Słowa kluczowe: Prawo, proces ustawodawczy, tworzenie prawa, doskonalenie prawa

\section{Bibliografia}

Albeski R., Trybunał Konstytucyjny w polskich systemach politycznych, Wrocław 2010;

Banaszak B., System prawa w Polsce - stan obecny $i$ uwagi de lege ferenda fundamentali, „Przegląd Legislacyjny" 2008, nr 4;

Bauman Z., Prawodawcy i tłumacze, Warszawa 1998;

Borski M., Glajcar R., Przywora B., Postępowanie ustawodawcze w Polsce. Prawo, zwyczaje i praktyka, Sosnowiec - Katowice - Częstochowa 2015;

Borucka-Arctowa M., O właściwy zakres regulacji prawnej, „Państwo i Prawo” 1975, nr 2;

Bożyk S., Opozycja parlamentarna w Sejmie RP, Warszawa 2005;

Bożyk S., Prawnoustrojowy status opozycji parlamentarnej w Sejmie Rzeczypospolitej Polskiej, Białystok 2005.

Chmielnicki P., Podmioty objęte procesem normotwórczym, [w:] P. Chmielnicki (red.), Pochodzenie, tworzenie i efektywność prawa, Warszawa 2014; 
Chodun A., Komunikatywność języka tekstów aktów prawnych, „Przegląd Legislacyjny" 2007, nr 2;

Chruściak R., Przygotowywanie rządowych projektów ustaw, „Przegląd Legislacyjny" 2004, nr 2;

Complak K., Opozycja parlamentarna w obowiazujacej i przyszłej Konstytucji RP, „Przegląd Sejmowy" 1995, nr 2;

Cyrul W., Wpływ procesów komunikacyjnych na praktykę tworzenia i stosowania prawa, Warszawa 2012;

Dobrowolski M., Zasada dwuizbowości parlamentu w polskim prawie konstytucyjnym, Warszawa 2003;

Dudzińska A., System zamknięty. Socjologiczna analiza procesu legislacyjnego, Warszawa 2015;

Działocha K., Trzciński J., Wójtowicz K., Studia nad udziatem grup interesów w procesie tworzenia prawa, Wrocław 1978;

Garlicki L., Zubik M., Ustawa w systemie źródeł prawa, [w:] A. Szmyt (red.), Konstytucyjny system źródeł prawa w praktyce, Warszawa 2005;

Gromaski W., Repel J., Niektóre kierunki i formy uspołecznienia procesu tworzenia prawa w krajach Europy Środkowo-Wschodniej, [w:] K. Działocha (red.), Problemy tworzenia prawa w państwie demokratycznym, Wrocław 1993;

Groszyk H. , Korybski A., Instytucje prawne uspołecznienia procesów prawotwórczych, [w:] H. Rot (red.), Państwo, Prawo, Społeczeństwo. Zbiór studiów, Wrocław 1992;

Gwidż A., Zagadnienia parlamentaryzmu w Polsce Ludowej, Warszawa 1972;

Jarosz Z., Postępowanie ustawodawcze w Sejmie, [w:] J. Wawrzyniak (red.), Tryb ustawodawczy a jakość prawa, Warszawa 2005;

Jaskiernia J., Regulacja prawna procedur parlamentarnych, „Państwo i Prawo" 1994, nr 12;

Jaskiernia J., Zasady demokratycznego państwa prawnego w sejmowym postępowaniu ustawodawczym, Warszawa 1999;

Karp J., Szymanek J., Profesjonalizacja parlamentarnych prac ustawodawczych, "Przegląd Sejmowy" 2009, nr 5;

Kruk M., Funkcja kontrolna Sejmu RP, Warszawa 2008;

Kruk M., Parlament $w$ dobie transformacji, [w:] M. Kruk, J. Wawrzyniak (red.), Transformacja ustrojowa w Polsce. 1989-2009, Warszawa 2011;

Kruk M., Rozważania o ksztattowaniu się zwyczajów i obyczajów politycznych w praktyce konstytucyjnej, [w:] K. Działocha (red.), Przeobrażenia we wspótczesnym prawie konstytucyjnym, Wrocław 1995;

Krzewińska A., Deliberacja. Idea, metodologia, praktyka, Łódź 2016;

Kubuj K., Rola Marszałka Sejmu w postępowaniu ustawodawczym, „Przegląd Legislacyjny" 2004, nr 2;

Kustra E., Polityczne problemy tworzenia prawa, Toruń 1994;

Kustra E., Proces ustawodawczy jako proces informacyjny, [w:] K. Grajewski, J. Warylewski (red.), Informacja prawna a prawa obywateli, Sopot 2006; 
Kustra E., Władczy i negocjacyjny typ tworzenia prawa, „Ruch Prawniczy, Ekonomiczny i Socjologiczny" 1994, nr 4;

Langer T., Amerykańska wersja analizy systemowej w nauce o państwie, Warszawa 1977;

Litwin T., Funkcje Sejmu i Senatu a współczesny polski model dwuizbowości, Warszawa 2016;

Łopatka A., Kryteria jakości prawa, [w:] A. Wasilkowski (red.), Jakość prawa, Warszawa 1996;

Nowak L., Próba metodologicznej charakterystyki prawoznawstwa, Poznań 1968;

Machelski Z., Opozycja w systemie demokracji parlamentarnej. Wielka Brytania, Niemcy, Włochy, Warszawa 2001;

Merten D., Ustawodawstwo w państwie prawnym. Możliwości, wyzwania, zobowiazania, [w:] H. Suchocka (red.), Tworzenia prawa w demokratycznym państwie prawa, Warszawa 1992;

Mijel T., Europejska kultura prawna a kraje Europy Środkowej i Wschodniej, „Przegląd Legislacyjny" 2008, nr 1;

Mistygacz M., Rząd w procesie ustawodawczym w Polsce, Warszawa 2012;

Mołdawa T., Procedura legislacyjna w Hiszpanii, „Przegląd Sejmowy” 1993, nr 4;

Olszówka M., Ustawy wyznaniowe. Art. 25 ust. 5 Konstytucji RP. Próba interpretacji, Warszawa 2010;

Patyra S, Tryb pilny w sejmowym postępowaniu ustawodawczym - reguła czy wyjatek?, [w:] W. Brzozowski, A. Krzywoń (red.), Leges ab amnibus intellegi debent. Ksiega XV-lecia Rzadowego centrum Legislacji, Warszawa 2015;

Piotrowski R., Parlamentarna kontrola kostyczności aktów prawnych, [w:] E. Zwierzchowski (red.), Prawo i kontrola jego zgodności z konstytucja, Warszawa 1997;

Piotrowski R., Racjonalność, rzetelność i sprawność jako przesłanki oceny zgodności ustawy z konstytucja, [w:] P. Mikuli A. Kulig, J. Karp, G. Kuca (red.), Ustroje. Tradycje i porównania. Ksiega jubileuszowa dedykowana prof. dr. hab. Marianowi Grzybowskiemu w siedemdziesiata rocznice urodzin, Warszawa 2015;

Piotrowski R., Spór o model tworzenia prawa, Warszawa 1988;

Pruszyński M., Jasność, zrozumiałość i językowa poprawność prawa jako warunek jego zgodności z Konstytucja, „Przegląd Legislacyjny” 2007, nr 1;

Popławska E., Lepsze prawo - wyzwanie dla Senatu, [w:] J. Wawrzyniak (red.), Tryb ustawodawczy a jakość prawa, Warszawa 2005;

Radziewicz P., Doradztwo naukowe w pracach Sejmu, „Przegląd Sejmowy” 2013, nr 5;

Rot H., Uwarunkowania i wartości procedury prawotwórczej, [w:] K. Działocha (red.), Problemy tworzenia prawa w państwie demokratycznym, Wrocław 1993;

Rot H., Wartości proceduralne tworzenia prawa. Studium legislacji porównawczej, Wrocław 1992;

Rzucidło J., Rząd elektroniczny. Aspekty konstytucyjnoprawne, Warszawa 2015;

Sarnecki P., Senat RP i jego relacje z Sejmem (lata 1989-1993), Warszawa 1995; 
Sobczyk P., Ustawa jako akt parlamentu ustanowiony w szczególnym trybie, [w:] M. Karpiuk (red.), Akty normatywne i administracyjne, Warszawa 2009;

Sokolewicz W., Niektóre zagadnienia procedur parlamentarnych w świetle orzecznictwa Trybunału Konstytucyjnego, [w:] F. Rymarz, A. Jankiewicz (red.), Trybunat Konstytucyjny. Ksiega XV-lecia, Warszawa 2001;

Stohanzl R., W sprawie organizacji naukowych stużb doradczych parlamentu, [w:] H. Suchocka (red.), Tworzenia prawa w demokratycznym państwie prawa, Warszawa 1992;

Syryt A., Kontrola trybu uchwalenia ustawy przed Trybunałem Konstytucyjnym, Warszawa 2014;

Szmyt A., Badanie dopuszczalności projektu ustawy w trybie art. 34 ust. 8 regulaminu Sejmu, „Przegląd Sejmowy” 2012, nr 5;

Szmyt A., Komisja mediacyjna w RFN, "Przegląd Sejmowy” 1993, nr 3;

Szymt A., Opiniodawczo-doradcza obsługa sejmowych prac ustawodawczych, [w:]

M. Kudej (red.), W kręu zagadnień konstytucyjnych, Katowice 1999;

Szmyt A., Tryb stanowienia ustawy - szanse i zagrożenia, [w:] M. Granat (red.), Zagadnienia prawa parlamentarnego, Warszawa 2007;

Szmyt A., Węzłowe problemy procesu legsialcyjnego w Sejmie i Senacie RP, [w:] R. Arnold (red.), Festgabe zu Ehren von Andrzej Szmyt. Ausgewählte Schriften, Regensburg 2016;

Szymanek J., Funkcja ustawodawcza parlamentu (w ujęciu analizy politologicznej), „Przegląd Legislacyjny” 2006, nr 2;

Szymanek J., Postepowanie mediacyjne w parlamencie dwuizbowym, "Przegląd Sejmowy" 2004, nr 5;

Szymanek J., Sejm, Senat a Trybunat Konstytucyjny. Wspótzależności w ksztattowaniu systemu prawnego państwa, "Przegląd Legislacyjny” 2004, nr 4;

Szymanek J., Udziat czynnika eksperckiego w procesie ustawodawczym, [w:] W. Brzozowski, A. Krzywoń (red.), Leges ab amnibus intellegi debent. Księga XV-lecia Rzadowego centrum Legislacji, Warszawa 2015;

Winczorek P., Opinia w sprawie postępowania legislacyjnego w przepisach regulaminu Sejmu Rzeczypospolitej Polskiej, „Przegląd Sejmowy” 2000, nr 2;

Witkowski Z., Postępowanie ustawodawcze we Włoszech, [w:] E. Zwierzchowski (red.), Postępowanie ustawodawcze, Warszawa 1993;

Wołpiuk W.J., Lobbing a demokratyczne formy wpływu na stanowienie prawa, [w:] J. Wawrzyniak (red.), Tryb ustawodawczy a jakość prawa, Warszawa 2005;

Wronkowska S., Opinia w sprawie postepowania legislacyjnego w przepisach regulaminu Sejmu rzeczypospolitej Polskiej, "Przegląd Sejmowy” 2000, nr 2;

Wronkowska S., Podstawowe pojęcia prawa i prawoznawstwa, Poznań 2003;

Wronkowska S, Proces prawodawczy dwóch dekad: sukcesy i niepowodzenia, „Ruch Prawniczy, Ekonomiczny i Socjologiczny" 2009, nr 2;

Wronkowska S., Tworzenie prawa w Polsce: ocena i proponowane kierunki zmian, „Przegląd Legislacyjny" 2006, nr 1; 
Wronkowska S., Zasady przyzwoitej legislacji w orzecznictwie Trybunału Konstytucyjnego, [w:] M. Zubik (red.), Księga XX-lecia orzecznictwa Trybunału Konstytucyjnego, Warszawa 2006;

Wronkowska S., Z historii ustawy o tworzeniu prawa, [w:] M. Kłodawski, A. Witorska, M. Lachowski (red.), Legislacja czasu przemian. Przemiany w legislacji. Ksiegga jubileuszowa na XX-lecie Polskiego Towarzystwa Legislacji, Warszawa 2016;

Wronkowska S, Wróblewski J., Projekt ustawy o tworzeniu prawa, „Państwo i Prawo" 1987, nr 6;

Wróblewski J., Epistemologiczne i aksjologiczne uwarunkowania tworzenia prawa, "Studia Prawno-Ekonomiczne" 1979, t. XXII;

Wróblewski J., Polityka tworzenia prawa a hierarchia wartości, „Państwo i Prawo" 1983, nr 9;

Wróblewski J., Ustawa o tworzeniu prawa a pojęcie prawa i prawoznawstwa, „Państwo i Prawo" 1977, nr 8/9;

Zaleśny J., Dynamika procedur interpelacyjnych. Doświadczenia okresu transformacji w wymiarze wertykalnym, [w:] M. Kruk, J. Wawrzyniak (red.), Transformacja ustrojowa $w$ Polsce. 1989-2009, Warszawa 2011;

Zaleśny J., Zasady prawidłowej legislacji, „Studia Politologiczne” 2009, vol. XIII;

Zawadzki S., Mazur J., Piotrowski R., Kryteria optymalizacji decyzji państwowych, [w:] A. Bodnar, W. J. Szczepański (red.), Decyzje polityczne w systemach społecznych, Warszawa 1987;

Ziembiński J., Problemy podstawowe prawoznawstwa, Warszawa 1980;

Ziółkowski, Standard legalności stanowienia ustawy w orzecznictwie konstytucyjnym, [w:] P. Radziewicz (red.), Kontrola legalności ustawy w Sejmie, Warszawa 2015;

Zwierzykowski P.E., Nowelizacja jako sposób zmiany prawa. Studium z teorii legislacji, Poznań 2016;

Zubik M., Prawo parlamentarne i postepowanie ustawodawcze w orzecznictwie Trybunału Konstytucyjnego, [w:] Trybunał Konstytucyjny. Ksiega XV-lecia, Warszawa 2001.

\section{DISFUNCTIONS OF THE POLISH LAW AND DIRECTIONS OF ITS PERFECTION AT THE LEGISLATION STAGE}

\section{S u m m a r y}

Article take two main issues. The first are the dysfunctions of the law, the second possibility directions of its improvement, in terms of the legislative process. Disadvantages of Polish law are different. These include, among other things, inflation law, his little clarity, the lack of clear axiological foundations, transgression understood as crossing areas by material acts arranged at different levels in the hierarchy of legal acts. Drawbacks of law are also the 
too frequent changes and excessive instrumentation. Therefore, there is need to improve the legislative process. It seems that the change should correspond to a few basic terms. Each course includes a number of smaller items, which should also be subject to any adjustments. They are directional indications: 1 ) the legislative process should be more rational; 2) the legislative process should be more professional; 3 ) the legislative process should be more socialized; 4) the legislative process should be more controlled and 5) legislative process should be more effective.

Keywords: Law, legislative process, making of the law, improvement of law

\section{ДИСФУНКЦИИ ПОЯЬСКОГО ПРАВА И НАПРАВ ЯЕНИЯ ЕГО УСОВЕРШЕНСТВОВАНИЯ НА СТАДИИ ЗАКОНОДАТЕДЬНОГО ПРОЦЕССА}

$$
\text { P е } 3 \text { ю м е }
$$

Статья анализирует два основных вопроса. Первым являются дисфункции закона, вторым направления ее совершенствования, с точки зрения законодательного процесса. Есть раздичные недостатки подьского законодательства. К ним относятся инфляция закона, его неясность, отсутствие четких основ аксиологических, трансгрессия - как пересечение законодательными актами материальных областей, расположенных на разных уровнях в иерархии правовых актов. Недоработками права являются также слишком частые изменения и инструментализация. Таким образом, существует необходимость совершенствования законодательного процесса. Кажется, что изменение доджно соответствовать нескольким основным условиям. Каждый включает в себя ряд более мелких элементов, которые также должны быть предметом каких-либо корректировок. Являются ними: 1) законодательный процесс должен быть более рациональным; 2) законодательный процесс должен быть более профессиональным; 3) законодательный процесс должен быть более социализированым; 4) законодательный процесс должен быть более управляемым и 5) законодательный процесс должен быть более эффективным.

Кдючевые слова: закон, законодательный процесс, создание закона, совершенствование закона 